\title{
LegAl RESOURCE NEEDS IN SMALL STATES (COMMONWEALTH PACIFIC JURISDICTIONS)
}

\author{
$\operatorname{Dr} G$ P BARTON QC*
}

This report by Dr Barton was the result of a survey of the legal resource needs of small Commonwealth states in the Pacific commissioned by the Commonwealth Secretariat in 1979. Dr Barton spent a month and a half visiting the 8 nation states between May and October of 1979. The terms of reference focussed on obtaining a factually based profile of the legal-constitutional needs of each state and are reflected in the various sections of the report. In particular, the terms of reference directed Dr Barton to "examine ways in which the special legal requirements of these jurisdictions may most effectively and efficiently be met bearing in mind the limited resources available and seeking to make maximum use of assistance which it might be possible to arrange from other institutions (for example, from university law faculties) and in close collaboration with existing regional institutions in the Pacific". In response to this Dr Barton suggests, among other things, a regional legal unit to serve the area, a suggestion which still has relevance today. Although $\mathrm{Dr}$ Barton's ideas for a regional advice unit were never implemented it is significant that a Pacific Law Unit for training purposes was established in Vanuatu with Commonwealth Secretariat and New Zealand Government support and latterly a regional law school has been established in Vanuatu by the University of South Pacific. In particular his comment that "in newly independent territories the need for legislative texts that are both up-to-date and readily available is particularly urgent" found a response in Victoria University Law Faculty based legislation master lists (Samoa, Solomon Islands) and in consolidated collections for Cook Islands, Niue, Norfolk Island and Tokelau.

\section{INTRODUCTION}

At the request of the Commonwealth Secretariat I undertook an assignment, financed by the Commonwealth Fund for Technical Co-operation (CFTC), which necessitated visits to various Commonwealth countries in the Pacific area. My function was to gain information about the legal resources of the countries that I visited and to assess the range

- Former Professor and Dean of the Faculty of Law, Victoria University of Wellington. 
and degrees of technical assistance that might be most effectively offered by the CFTC and related agencies, bearing in mind other sources of technical assistance that were or might be available.

The terms of reference which formed the basis of my assignment are set out in Appendix A to this Report. ${ }^{1}$ In each country visited I emphasized that I was not to be viewed as an 'expert' with a catalogue of instant solutions for every problem that might be encountered in providing a full range of legal services. I made it clear that my role was essentially that of a listener, trying to assess as best I could the needs in each country and meshing those needs into the range of assistance that might be available from the Commonwealth Secretariat, the CFTC, and related agencies.

Although the terms of reference were always used as the basis for initial discussion, I encouraged those with whom I spoke not to feel rigidly confined to them. As a result there were occasions when topics were raised that provided opportunities for a limited range of assistance reports on legal topics to Cabinet; to express views as to the suitability of candidates for particular legal posts; to consider and discuss proposed legislation; to give constitutional advice; and even, in one case, to translate a diplomatic message received by cable in French. In every instance I made it clear that such assistance was being given on a personal and informal basis, justified solely by the fact that the requests for assistance was made while I was involved in discussions. That the requests for assistance on-the-spot should have been made so frequently is itself a measure of the feeling of isolation experienced by many legal advisers in Commonwealth Pacific territories.

Wherever I went, I received a warm welcome, and was offered generous hospitality. Many persons in the countries visited made themselves available for full discussions. Some of them devoted a great deal of time to giving me assistance. This, I am conscious, must have made considerable inroads into their time. They were, invariably, kind enough to say that they had found the discussions very helpful to themselves, but nevertheless their own programmes of work must have been affected to a degree. Wherever I went there was universal appreciation for the initiative of the Secretariat and for the assistance that is at present being made available, especially through the good offices of the Legal Division. There was total acceptance of the value of co-operation within the Commonwealth and an eagerness to be involved in regional co-operative schemes of legal assistance.

There were many others from whom I derived helpful insights into the context of the legal systems concerned. In the countries that I visited there was hardly a single person,

1 The Appendices are not reproduced here. 
lay or professional, who did not in some measure contribute to my better understanding of the situation to be assessed.

Broadly speaking I shall deal in this report with the individual topics covered in my terms of reference, but sometimes grouping certain topics under a general heading. After expressing some comments pertinent to the subject-matter I shall make specific reference to individual countries.

Under the first main heading I shall deal with the question of legal resources generally. That will cover a survey of the present position in the various countries with an indication of the areas in which there is a need for further legal manpower at various levels.

In the next main part of the report I shall deal with resources in terms of the statutebook and law reporting, these being topics explicitly mentioned in my terms of reference.

Next I shall deal with the legal needs in the area of foreign affairs in various countries. Under a separate heading I shall deal with questions of legislative drafting and training needs.

The countries that I visited in the course of my survey included New Hebrides. As is well known, the legal status of New Hebrides is that of an international and constitutional condominium. No fewer than four separate legal regimes co-exist in that territory. My entree, so to speak, was through the British Administration. I had opportunities to discuss legal matters generally with persons involved in the French Administration and in the New Hebridean Administration (which is in the process of evolving into the government of the emerging independent New Hebrides). But it would be misleading to suggest that any assessment of the legal needs of the independent New Hebrides was or could have been undertaken at that stage. In short the visit to that territory was premature by about a year. There was general agreement among those with whom I had discussions that a similar visit after independence would be extremely valuable. Accordingly, rather than deal with the position in the New Hebrides under various headings in this report I have included a separate memorandum in Appendix D relating to the New Hebrides.

\section{LEGAL RESOURCES}

The concept of 'legal resources' is not a precise one. In the final analysis legal resources cannot be isolated from human resources as a whole. The legal needs of a society depend upon the domestic nature of that society and its relationship to the world in general and to other states in particular. Then too, it is necessary to know what is meant by 'law' in any given society, before it is possible to determine that society's legal resources. In my task I was driven to take a pragmatic view of my terms of reference, confining myself in the time available to the kind of law and the type of legal resources which would be familiar to a lawyer trained in the English common law and British constitutional tradition. Such an 
approach automatically excluded consideration of the needs and resources of many important customary law systems.

And yet I could not be entirely unaware that in many, if not in most, of the jurisdictions that I visited the law that affected the vast majority of the people - what they would think of as 'law' - was the system of traditional customary law that had provided the framework within which they had grown up and would live out their lives. That customary law deals with the two highly important foci of concern in the structure of Pacific societies - I say nothing of other societies. The first is constituted by the relationships and obligations within family groups and between various family groups. The second, which in varying degrees may overlap with the first, is constituted by the relationship between a person (within family groups) and land. In my discussions with lawyers and others in each jurisdiction that I visited, in my reading and consideration of the legal condition of each state, I formed the view that no lasting satisfactory system can be evolved which does not have at its heart an understanding of these basic and central realities. Law that is lent from the outside, no matter how well-meaning the lender may be, will ultimately prove unsatisfactory and unsatisfying unless it meets those fundamental needs. So too the local society should not borrow from the outside unless the same conditions apply. Neither a borrower nor a lender be!

Accordingly I approached my task with an acute awareness that as an outsider I was attempting to mediate to the Commonwealth Secretariat the needs of various jurisdictions which, almost by definition, lay outside my ken. Conversely I was attempting to convey to those lawyers and officials the facilities that might be made available and the assistance that might be provided to meet needs which as a 'foreign' lawyer I could not fully understand. Notwithstanding the inherent problems of understanding the 'real' legal system the exercise on which I was engaged could be carried through in a pragmatic way and with a conscious recognition of the limitations applying to the task.

In any survey of legal resources it is important to remember that there is great mobility among legal personnel. Particularly in the case of expatriates there is no permanency. Short term contracts are almost the invariable rule. Because of extreme shortages of staff swift ad hoc changes are often imperative. Occasionally officials with whom I had corresponded about my approaching visit to their territory had either changed their particular work by the time that I arrived or had moved to some other territory. Where there are local lawyers in government positions frequent changes also take place. Furthermore, movements in personnel are matched by the re-appraisal of the staffing establishment position, so that it is extremely difficult to gain a completely precise picture of the establishment at any given time that will necessarily remain unchanged for even a short period. The following survey of individual territories should be seen in the light of the permanently changing pattern. 


\section{A Cook Islands}

\section{Judiciary}

Under Part IV of the Constitution of the Cook Islands provision is made for the establishment of the High Court, the Land Court, and the Land Appellate Court of the Cook Islands, and for the appointment of Judges and Commissioners to those Courts. All judges and commissioners up to the present time have been New Zealanders, many with previous judicial experience. The Land Appellate Court, established by Article 55 of the Constitution, consists in fact of the Judges of the Land Court and of the Maori Land Court of New Zealand.

\section{Government Legal Services}

The principal legal adviser to the Government is the Advocate-General of the Cook Islands. His appointment depends, not upon any constitutional provision, but upon the exercise of the prerogative power. The Advocate-General appears for the Government and for statutory bodies in Courts and tribunals, as well as before the Supreme (now High) Court of New Zealand: see Maurangi v High Commissioner of the Cook Islands [1975] 1 NZLR 557. The present Advocate-General is a New Zealand lawyer with experience both in East Africa and in New Zealand. His post is a United Nations Development Plan position, and the appointment is funded on an ongoing basis by the scheme of operational assistance (OPAS) between the United Nations and the Cook Islands.

The Advocate-General is the only qualified lawyer in the Government service, apart from the legal officer to the Justice Department (Mr Tere Mataio). The Advocate-General has one unqualified assistant and one secretary. Virtually, if not entirely on his own, the Advocate-General undertakes the total range of legal work for the Government. He attends to all legislative drafting, although in some instances a draft piece of legislation will be initiated in the office of the Department concerned. Not only is he the sole legal adviser to the Government, but he represents the Public Service before the Public Service Board of Appeal, and is involved in work relating to the re-organisation of the Public Service following upon inquiry into the public service recently undertaken by a New Zealand lawyer at the request of the Cook Islands Government. To some extent the demands upon the Advocate-General are lessened by the authority given to him under arrangements made with the Government, to retain lawyers outside the Cook Islands to accept instructions on specific assignments. A substantial amount of advisory work is undertaken for the Cook Islands Government in this way by the firm of Messrs Russell, McVeagh, McKenzie, Bartleet \& Co, Solicitors, Auckland, New Zealand. One member of that firm (Mr B H Giles) has acted as Advocate-General on occasions. It would seem to be desirable for the Government to build up its own legal resources and progressively to reduce its reliance upon outside sources. 
In many important administrative offices it is of great advantage to appoint a person with legal qualifications and experience. However, as has been mentioned, the only qualified officer is the Legal Officer to the Justice Department. There is a clear need for further appointments.

There are, in fact, eight qualified lawyers in the Cook Islands, four of whom are either in private practice on their own account or in private employment, and two of whom hold Cabinet positions in the present Government. There are three or four students from the Cook Islands undertaking legal studies abroad either in Australia or in New Zealand. One of them has attended a law drafting course at Canberra, and it is hoped that eventually she will take up a government post in the Cook Islands. On any view of the matter it will be many years before the Cook Islands will be able to provide a full range of legal services without relying upon expatriate assistance.

\section{B Fiji}

\section{Judiciary}

At the apex of the Fijian legal system is the Fijian Court of Appeal consisting of four Judges. At the time of my visit none of the Judges of that Court was a native-born Fijian and only the Chief Justice has any formal link with Fiji, the remainder being either present or former Judges of the Supreme (now High) Court of New Zealand or the former holders of high judicial office in a Commonwealth Pacific territory. In addition to the appellate jurisdiction conferred upon it by Fijian law the Court is also the ultimate court of appeal from certain other Commonwealth Pacific jurisdictions.

The Supreme Court of Fiji consists of a Chief Justice and five puisne Judges. Since my visit to Fiji the former Chief Justice has retired from office and he has been succeeded by a local Fijian Judge (Mr Justice Tuivaga). Three of those five are expatriates.

There are, in theory, three grades of magistrate, but in practice appointments are made only at the level of senior magistrate (first class). There are eleven Senior Magistrates (one of them being designated Chief Senior Magistrate). Of the Senior Magistrates only a few are native-born Fijians. The Chief Senior Magistrate is one of those. One of the Senior Magistrates also exercises jurisdiction in Tuvalu under Tuvaluan law.

All appointments are made by the Judges and Legal Services Commission, an independent body established under the Constitution. As far as I could ascertain, there is no explicit selection or appointment policy based upon an early phasing out of reliance upon expatriate judges. 


\section{Government Legal Services}

Fiji possesses a well-developed system of public prosecutions. The Director of Public Prosecutions is from Sri Lanka and is funded through the United Kingdom Government (OSAS). His office staff consists of a Chief Legal Officer, three principal legal officers (all from the United Kingdom); two senior legal officers (both Fijian); and an establishment of four legal officers (two of whom are Fijian, two appointments pending). All of the legal personnel in the office of the Director of Public Prosecutions are legally qualified. Thus out of a staff of eleven in the Office, only four are Fijian in origin. There is ample room for increasing the involvement of suitably qualified Fijian lawyers in this vital constitutional office, and not only at a junior level.

Crown Law Office is the permanent legal department advising the Government in Fiji. The establishment consists of:

Solicitor-General

Deputy Solicitor-General

First Parliamentary Counsel

Second Parliamentary Counsel

Crown Solicitor (Civil)

Crown Solicitor (Commercial)

Principal Legal Officer

Senior Legal Officer

Legal Officers (4) (an office assumed by a native born Fijian in May 1979)

(vacant)

(one post filled by CFTC attachment and the other, at present vacant, to be funded by the United Kingdom Ministry of Overseas Development (ODM))

(vacant)

(this officer had been seconded to the Inland Revenue Department)

(one of these officers had been seconded to the Lands Department; one acted as a parliamentary draftsman (part-time); and another was seconded to the Ministry of Foreign Affairs)

There are difficulties in maintaining the establishment up to its full complement. The Office is the obvious reservoir for legal assistance to other departments. The Department of Social Welfare employs a public legal adviser (at the level of principal legal officer) 
whose functions include providing some legal assistance, chiefly in domestic cases, to applicants for social welfare grants.

\section{Private Practice}

Fiji is one of the few Commonwealth jurisdictions in the central Pacific region with a sizeable legal profession. There are approximately 130 lawyers in Fiji, of whom about 90 are in active practice. That represents a $50 \%$ increase in less than five years. The Fiji Law Society provides a professional focus for the practising lawyers in the country: an annual subscription is devoted to the holding of seminars and social functions.

\section{Kiribati}

Until independence the Fijian Court of Appeal was the ultimate appellate tribunal from Kiribati. Now however the Court of Appeal of Kiribati has been established, consisting of the holders of high judicial office in other Commonwealth Pacific jurisdictions. That Court held its inaugural sittings in October 1979.

The Supreme Court of Kiribati consists of one Judge, the Chief Justice. The present holder of that office, like all of his predecessors, is an expatriate.

The Chief Registrar of the High Court is responsible for the financial and general administration of the Magistrates Courts. At the time of my visit the holder of the office was in fact a locum tenens, having been originally recruited to assist the Attorney-General. She is legally qualified in the United Kingdom, and has been appointed under a short-term contract.

The Attorney-General is, and always has been, an expatriate. The first AttorneyGeneral under the Constitution was temporarily appointed to meet an unexpected emergency that had arisen. On the appointment of the permanent Attorney-General (formerly in the Office of the Director of Public Prosecutions in Fiji) he was to resume his interrupted assignment on behalf of CFTC to advise on the extent to which amendments to the existing laws of Kiribati may be necessary to achieve conformity with the Constitution. Under the Constitution of Kiribati the Attorney-General is not only the principal legal adviser to the Government but is also by virtue of his office a member of Cabinet: see Articles 40 and 42.

The Attorney-General is assisted by a recently qualified lawyer, designated State Counsel (Mr Michael Takabwebwe), who is the only Kiribati lawyer working for the Government. Mr Takabwebwe was shortly to attend a course in the United Kingdom organised by the British Council for Government legal officers. The Director of the course is Sir William Dale. 
It will be apparent that the few legally qualified persons in Kiribati are carrying a heavy burden. Only one of them is Kiribati born and bred and he is recently qualified.

\section{Solomon Islands}

\section{Judiciary}

At first instance there are five Magistrates, including one appointed as a Principal Magistrate. Of those five only two are legally qualified. Four of the Magistrates (including the two legally qualified) are expatriates. For geographical reasons it is highly desirable, and perhaps necessary, to arrange for individual magistrates to be appointed to specific districts. The result however is that some magistrates in sparsely populated districts have a less demanding workload than their colleagues in more populous districts. There is a clear need for assistance in the Central District. Another consequence of the lack of qualified personnel is that some judicial officers may be called upon to undertake other functions. For example, the Principal Magistrate (at the level of Chief Judicial Officer) was, at the time of my visit to Solomon Islands, carrying out the duties of the Registrar of the High Court and also temporarily performing the duties of District Magistrate for the Central District.

The High Court consists of one Judge (the Chief Justice) who is an expatriate. The administrative work of the Court is a responsibility of the Registrar who is at present doubling as Principal Magistrate. He too is an expatriate. Appeals lie from the High Court to the Fijian Court of Appeal (which for this purpose is part of the legal structure of Solomon Islands).

\section{Government Legal Service}

The Attorney-General is the principal legal adviser to the Government. The present Attorney-General is an expatriate with a wide experience in legislative drafting in the New Hebrides. The establishment contemplates the appointment of a Solicitor-General, but no current provision was available to fund an appointment. There are two Assistants to the Attorney-General, both of them native-born Solomon Islanders and both graduates from the Faculty of Law at the University of Papua-New Guinea. Unfortunately neither of them had been admitted as law practitioners in Papua-New Guinea and consequently neither is entitled to be admitted to practise in Solomon Islands as the law now stands. That impediment does not apply while they are engaged in the Government legal service, but it would prevent them from entering private practice. Also on the establishment are two posts at the Senior Crown Counsel level, one for civil work and the other on the criminal law side. No financial provision is available for either of these; but it is contemplated that, if and when appointments can be made, the officers appointed will be expatriates. At the level of Crown Counsel it is contemplated that two appointments will be made shortly of Solomon Islanders who have recently graduated. 
In the Ministry of Law and Information there is an establishment post for a legislative draftsman which was at the time of my visit on offer to an expatriate who was engaged in Papua-New Guinea on law drafting. In the Registrar-General's Department within that Ministry there is a qualified lawyer (also an expatriate) responsible for a wide range of legal work relating to land titles. He has no qualified legal assistants at all, and experiences the common difficulties of training unqualified staff and of retaining them once trained.

\section{Constitutional Posts}

Two particular constitutional posts should be mentioned. Under Part III of the Constitution provision is made for the appointment of a director of Public Prosecutions (Article 91) and of a Public Solicitor (Article 92). By Article 143 of the Constitution those two offices (together with that of Ombudsman) are to be established no later than 8 July 1981.

Once a Director of Public Prosecutions has been appointed, he will take over ultimate responsibility for the conduct of criminal prosecutions from the Attorney-General, whose functions will be revived when there is no Director of Public Prosecutions or when the Director is for any reason unable to perform his functions under the Constitution. It is difficult to forecast the number of legally qualified assistants that the Director may need, and varying estimates were mentioned in discussions.

The office of Public Solicitor is comparatively new in the Pacific Commonwealth region. His main function will be to provide legal aid, advice and assistance to any person charged with a criminal offence. He is also to provide such aid, advice, and assistance in other matters when directed to do so by the High Court. The establishment of such a post is a commendable initiative to overcome the almost total lack of legally qualified persons in private practice. Until the establishment of the constitutional post of Public Solicitor much of the work that he will be doing is at present being undertaken by two Social Welfare Solicitors, both of them young expatriate lawyers (one of them a New Zealand lawyer) engaged by Volunteer Service Overseas in the United Kingdom. The fact that persons, normally unable to afford to pay for legal services even if they were available, now have legal representation carries important implications for Government Departments involved in litigation with private citizens and especially for the Police. Most prosecutions at the level of the District Courts are conducted by police officers, not qualified in law and not experienced in coping with cases where the defendant is professionally represented. It is virtually inevitable that on the appointment of a Director of Public Prosecutions there will be an obvious need and a very strong case for the addition to his office of properly qualified legal staff. 


\section{Provincial Level}

Proposals are being considered for enlarging the power of the District Councils in the constituent Provinces of Solomon Islands. Suggestions have been made that provision should be made for the appointment of lawyers to act as legal advisers to individual District Councils. There seems to be no common agreement on the advisability of such provision. The reservations about the suggestion seem to be based on a forecast that there would be insufficient work: those who tend to favour the suggestion are optimistic that there would be sufficient work to justify such appointments. Which decision is the right one seems to depend on a fundamental judgement of a policy nature about the nature and degree of de-centralisation. It is wise to make provisional arrangements for properly qualified legal assistance at the provincial level in any event, reserving a decision on the quality and extent of that assistance as the degree of district autonomy and independent responsibility becomes clearly established.

\section{Tonga}

\section{Judiciary}

In Tonga the Supreme Court is a Court of general jurisdiction consisting of one Judge at present (the Chief Justice). The Chief Justice is, and always has been, an expatriate. The appointment of an extra Judge is contemplated, but the present Chief Justice does not regard the need as particularly urgent. The Supreme Court holds sittings as a general rule in the capital, but the Judge goes on circuit to the northern group of islands.

The Land Court is established as a Court of special jurisdiction consisting of a Judge and one assessor, a Tongan knowledgeable on Tongan customs and usages in relation to land.

Appeals lie from both Courts to the Tongan Privy Council which comprises the King of Tonga, the members of the Cabinet and an appointed Judge who advises the Court in the manner of a Judge Advocate. The judgement of the Privy Council is prepared by the judicial member of that body, who has for some years been a retired Judge of the Supreme Court of New Zealand. A Court of Appeal Act has been enacted for the purpose of placing the appellate work on a permanent and more explicitly legal basis, but the statute has not yet been brought into force.

\section{Government Legal Service}

The Crown Law Department is, as its name indicates, the instrumentality providing legal advice to the Government. The establishment consists of the Head of the Department who is designated Crown Solicitor (Mr David Tupou); a Crown Prosecutor; an Assistant Crown Solicitor; and a Legal Assistant. Only the posts of Crown Solicitor and Crown Prosecutor were filled at the time of my visit. Both of them are Tongan. The Crown 
Solicitor is very highly qualified and has a wide experience not only in law but also in administrative and diplomatic work. For a short two-year period from 1976 to 1978 the Crown Law Department consisted of three legally qualified persons when a United Kingdom lawyer was appointed (on OSAS terms) as Crown Prosecutor. That has been the only period when Tonga had the services of three lawyers in the Government Legal Service.

\section{E Tuvalu}

\section{Judiciary}

The judicial system of Tuvalu operates in the usual pattern at various levels. At first instance there are 8 Island Courts in Tuvalu with five lay Magistrates appointed for each Court, although in practice only three sit in any particular case, the remaining two acting as alternates. Their jurisdiction is limited to the hearing and determination of criminal charges where the punishment liable to be imposed does not exceed $\$ 60$ or 6 months imprisonment.

There is also a local lay Magistrate, with somewhat more extensive jurisdiction. At the apex of the system of inferior courts of general jurisdiction is the Senior Magistrate, an expatriate (Mr Moore SM) who visits Tuvalu from Fiji from time to time to deal with accumulated business of a more serious nature. As is not unusual in Pacific jurisdictions, the Senior Magistrate possesses certain powers of review and revision with respect to the decisions of the lay Magistrates at the local level.

Tuvalu has a High Court, and has appointed as its Chief Justice the current Chief Justice of Solomon Islands. It is expected that he may visit Tuvalu to hold sittings of the High Court more or less annually. In between his visits he deals with the business of the Court 'on the papers', by reading the documents transmitted to him in Solomon Islands by the Registrar. A substantial part of such work consists of reviewing the decisions of the Courts of inferior jurisdiction. It is common practice for such matters to be disposed of without a sitting of the Court and without any appearance by or on behalf of the parties concerned.

The Registrar of the High Court discharges many varied functions: the current Registrar is also Clerk to the Senior Magistrate, Clerk to the Tuvalu Magistrates, and Clerk to Parliament. There is no legally qualified Tuvaluan available to service the work of the Courts. The office of the Prime Minister handles the administration of the Courts, and the Registrar is accordingly responsible to the Prime Minister.

\section{Attorney-General}

The Attorney-General of Tuvalu is the principal legal adviser to the Government. He is, in fact, the only legally qualified person permanently stationed within Tuvalu. $\mathrm{He}$ is an 
expatriate and engaged by the Government on a contract basis from the United Kingdom. Being the only lawyer in a country must be a daunting responsibility. Legal problems of all kinds, both governmental and private, tend to gravitate in his direction. Even defendants in criminal cases may look to him for advice, as happened when at the time of my visit the Master of a Korean fishing vessel arrested on a charge of fishing within Tuvaluan territorial waters sought the Attorney-General's advice as to his rights.

\section{F Western Samoa}

\section{Judiciary}

At the basic level there are eleven lay Magistrates (Fa'amasino Fesoasoani) who exercise limited criminal and civil jurisdiction. These Magistrates go 'on circuit' to various parts of Western Samoa. Although they have no legal qualifications, care is taken to appoint persons who by reason of their standing in the community and their relative noninvolvement in political matters would be generally accepted as impartial judges on the matters that come before them. By reason of their background and experience many of these Magistrates also hold office as Samoan Judges of the Land and Titles Court.

The Magistrates Courts exercise their jurisdiction throughout Western Samoa. There are two Magistrates: one, who is legally qualified, is an expatriate seconded on appointment from the Magistrates' Bench in New Zealand (now the District Court); and the other is a Samoan, a layman with experience as Secretary of Justice who has been previously appointed as acting Magistrate from time to time.

As a court with a special jurisdiction the Land and Titles Court has the exclusive authority to hear and determine matters relating to Samoan custom, titles, and land. In the context of Western Samoan society this Court discharges a most significant function which is regarded as of great importance by the vast majority of Samoans. The Court does not confine its sittings to Apia. It consists of a President (who is normally the Chief Justice) and Samoan Judges and Assessors. There are two Deputy-Presidents available to sit when the President is not able to sit in any particular case.

The Supreme Court, which is a court of general jurisdiction vested with constitutional powers, consists of a Chief Justice, although from time to time an additional Judge has been appointed. Since independence in 1961 the Chief Justice of Western Samoa has invariably been appointed from New Zealand, usually if not always from the Magistrates' Bench in New Zealand. The pattern has been for the Chief Justice to be appointed for a specific term, usually for three years.

The Court of ultimate appellate jurisdiction is the Court of Appeal of Western Samoa, consisting of the Chief Justice as President and two other Judges who are usually either 
present or former members of the Supreme Court Bench (now High Court) in New Zealand.

\section{Government Legal Service}

The Attorney-General, who holds his office under the Constitution, is the principal legal adviser to the Government. Until recently the persons appointed to the position of Attorney-General were expatriate from New Zealand, but the present holder of the office is a distinguished Samoan (Mr N Slade) with wide experience of Government legal work. In the Office of the Attorney-General there is a Parliamentary Counsel, an expatriate, who is responsible for legislative drafting. The first assistant to the Attorney-General is a Senior Legal Officer (Prosecutions). There are three establishment posts at the Legal Officer level, all of which are at present filled by Samoan lawyers. Apart from the Attorney-General and the Parliamentary Counsel, all of the staff in the Office of the Attorney-General have qualified within the last five years.

The Secretary for Justice is a layman, but with wide ranging responsibilities for legal matters - his Department services all of the Courts in the Western Samoan legal system; he is the Registrar of the Supreme Court and Court of Appeal; he is the Registrar of Companies, Co-operative Societies, Credit Unions and Incorporated Societies; the Registrar of Patents, Trade Marks and Industrial Designs; the Registrar of Lands; and the Registrar of Electors. There is no legally qualified person in his Department at all. This means that all questions that are perceived to have a legal character must be referred to the Office of the Attorney-General. It also means that those who administer legislation with a high 'legal' content may have a relatively undeveloped appreciation of that fact.

\section{Private Practice}

Western Samoa is comparatively fortunate in having a number of lawyers in private practice. And, of the 16 practising in that way either as principals in firms or as staff solicitors, all except four are Samoan.

\section{TRAINING OF LOCAL LAWYERS}

It will be apparent from the foregoing survey that there is a glaring lack of local lawyers in government service throughout the Pacific Commonwealth territories. Even in Fiji, the one Pacific jurisdiction with a sizeable legal profession, lawyers in Government are predominantly expatriate. Such a state of affairs is not in the best interests of any community. It is to be hoped that all of the Governments concerned will adopt a conscious and deliberate policy of providing opportunities for local citizens to acquire legal skills so that as soon as practicable a reservoir of properly qualified lawyers will be created from which the legal needs of Governments may be satisfied. In many of the countries that I visited I formed the impression that those responsible for manpower planning set their 
sights too low when it came to projecting the needs of their society for lawyers. Furthermore some of the planning was very much short term. Thus students who have been sent overseas for their training have, in some cases, been required to return immediately on graduating but before completing their professional qualifications. This is frustrating to the students concerned and ensures that they will continue to suffer a sense of grievance. It may also have adverse consequences upon their prospects for promotion. It savours of "spoiling the ship for a Ha'p'orth of tar".

The only University in the region is the University of the South Pacific with its headquarters in Fiji and with campuses and extension departments in nearly all of the countries that I visited. A deliberate policy was adopted at the outset that law would not be taught at the University. In that respect I consider that an excellent opportunity was lost for providing legal services to the countries in the South Pacific region. Even at this stage the University might be persuaded to re-consider that early decision and to institute courses at various levels for the training of lawyers.

In the meantime those who wish to obtain traditional legal qualifications are forced to seek them outside the region, often with assistance from Government scholarships. It has been common for such students to attend universities in New Zealand or in Australia, although in more recent years some students have graduated from the University of Papua-New Guinea. None of the universities in Australia or New Zealand attended by students from Pacific countries take any specific steps to cater for those students. They merge into the mass of students and have no option but to conform to the local pattern. In one sense there is much to be said for presenting a foreign student with the challenge of competing with other students from different cultures. But it can also be a daunting prospect. For some the strain has obviously been too much. And even the better-thanaverage foreign student has difficulties in coping with a strange environment and a completely new experience. It is a matter for regret that not one of the universities in Australia or New Zealand provides a course of study specifically designed for law students from Pacific territories. There is a strong case for establishing such a programme. There are some universities that have a long-established and keen interest in Pacific studies, where students from various Pacific territories have graduated in law along with local students, and where existing strengths in teaching and research would allow for an extension into the field of law courses specifically designed to meet the needs of law students from Pacific countries. If Governments can be persuaded that the long-term interests of the Pacific Commonwealth countries will be served in that way I am optimistic enough to believe that a university will be found that would be ready to offer such a facility.

In general discussions about law training the main emphasis is usually placed on traditional legal qualifications. There is, however, no reason why courses at a more 
modest level might not be feasible. There is a real need for the provision of legal services before customary law tribunals and also before lay judges. Even in the few cases that I listened to in Pacific territories it was apparent that parties before the Court had little appreciation of what was going on: misunderstandings and confusion were common. Intelligent persons with training in the elements of advocacy would have been of great assistance to the parties, and incidentally to the lay judges. This, of course, is a universal experience wherever a layman is involved in legal proceedings. In many parts of the English-speaking common law world courses for the training of legal executives are wellestablished. There is no reason in principle why courses could not be devised to train legal advocates in the elementary principles of representing persons who become involved in litigation before lay judges and tribunals administering customary law.

Some consideration has been given in Tonga to the establishment of training courses in elementary advocacy. In that country there is a system of licensed advocates under which Tongans who pass a short course of study may be admitted to practice. The students are required to do a good deal of reading on their own, but both the Chief Justice and the Crown Solicitor have in the past given lectures on some of the legal subjects in the course. I was informed that it is very difficult to arrange the teaching programme, which in any event throws yet another burden on shoulders that are already carrying excessive responsibility. It appears that no course of lectures has been offered for some years, and that it is some time since the law examinations have been held. About 60 Tongans have indicated an interest in taking such a course at the present time.

The Chief Justice of Tonga has arranged through the United Kingdom Ministry of Overseas Development for correspondence material to be sent out to Tonga. But in my view a radically different approach is called for. As is recognised in Tonga, it is extraordinarily difficult for Tongan students to cope with kind of course which would be available in an entirely different legal system and which presupposes an advanced understanding of the English language. Until there is general availability of Tongan material (statutes, law reports, books, and other teaching aids) it will continue to be extremely difficult for students to pass the advocates examination.

Short teaching courses based upon a realistic policy of legal education for licensed advocates should be established on a permanent footing. It is important that assistance should be given to ensure that such courses are as efficient instruments of legal education as the circumstances allow. The CFTC would be rendering a great service if it could arrange for someone to assist in the setting up of such courses and in the provision of teaching material for the students. What is true for Tonga applies with equal force in other Pacific territories. It is impracticable to contemplate the establishment of such courses in individual countries but there is no reason why training might not be offered on a regional basis. 


\section{A The Statute Book}

Unpublished law is a contradiction in terms. It is an indispensable requirement of any legal system worthy of the name that the enacted law must be promulgated. But formal promulgation is not enough. The text of enacted laws and regulations should always be readily available to everyone who is interested. And yet even in supposedly sophisticated jurisdictions the texts of the enacted laws are occasionally difficult to obtain. They are out of print. Or, more frequently, there have been so many amendments that it is beyond the wit of the ordinary citizen to keep up with the changes. Sometimes even the law-makers themselves are foxed by the plethora of changes.

In newly independent territories the need for legislative texts that are both up-to-date and readily available is particularly urgent. In all of them the current law will consist of an enormous and undigested corpus of legislation enacted by the metropolitan parliament and having continued force within the territory. The metropolitan legislation almost always crystallises at the date of independence. The only changes which will operate thereafter in the independent territory are those which the territory's own legislature may enact. Until the metropolitan legislation is entirely superseded by the local statutes there will be a continuing need for the text of that legislation, fixed at the point of independence, to be available as part of the body of enacted law in force in the territory.

But there are prior questions. How does one determine what metropolitan legislation is in force in any particular territory? Who reaches that determination? The determination of applicable metropolitan legislation itself depends upon the provisions of the local law. There may be, as there often is, a statute declaring the criteria for deciding which statutes are to be in force in the territory: other tests may be prescribed. Normally the determination is made by the Courts as and when a particular metropolitan statute comes before them for consideration. In such cases any other determination will be provisional, and may remain so for generations. In some of the constitutions of new independent Commonwealth states in the Pacific specific provision has been made on this subject. For instance, the Kiribati Independence Order 1979 (a United Kingdom order-in-council) provides in paragraph 5 as follows:

(2) The existing laws and any Act of the Parliament of the United Kingdom or Order of Her Majesty in Council (other than the Kiribati Act 1979 or this Order) having effect as part of law of Kiribati or any part thereof immediately before Independence Day shall be construed with such modifications, adaptations, qualifications and exceptions as may be necessary to bring them into conformity with this Order. 
(3) The Beretitenti may by order made at any time before 12th July 1980 make such amendments to -

(a) the existing laws; or

(b) any Act of the Parliament of the United Kingdom or Order of Her Majesty in Council (other than the Kiribati Act 1979 or this Order) having effect as part of the law of Kiribati or any part thereof immediately before Independence Day, as may appear to him to be necessary or expedient for bringing those laws or that Act of Parliament or Order into conformity with the provisions of this Order or otherwise for giving effect or enabling effect to be given to those provisions.

The ascertainment of what amendments may be necessary for the purpose of achieving conformity between existing laws and a constitution requires legal skills of a high order. The Commonwealth Secretariat has been able to assist in this task by arranging for highly experienced lawyers to undertake the work of preparing reports for submission to the governments concerned. There will be a continuing need for specialised assistance of that kind.

Important although metropolitan legislation may be, it is overshadowed by the growing body of local statutes, regulations, ordinances, and bylaws. With the evolution of responsible government the tempo of local legislation will have increased until on independence the greater part of the enacted law will be of local content. The need for public awareness of such legislation is even more important, and the difficulties of ensuring general availability are almost as great. It is of fundamental importance that the original text of enacted laws should be treated as sacrosanct; it should be deposited in the custody of a public official who should be responsible for its preservation and for granting access to those who wish to consult the ipsissima verba of the legislation. In one Pacific territory that I visited the assented text of the Acts was to be found in a manilla folder in a clerk's desk, the individual Acts not arranged in order, some missing, and many with unauthenticated handwritten alterations. Copies of legislation should be official and accurate copies, certified as such either on the copies themselves or by virtue of some general legislation, such as an Acts Interpretation Act. The official copies should be available at all times while the legislation is in force at some place at which Government publication may be obtained, such as a government printing office or bookshop.

The process of publishing legislation should not end there. Statutes are not like pieces of meccano which the uninitiated ought to be able to build up in reliance on their own devices. Governments should accept a continuing responsibility to ensure that an integrated text of legislation is always available, and where frequent amendments have 
taken place that a fresh statute should be enacted. Furthermore, the legislator should realise that the language of enacted law is often baffling to the layman and should provide with every piece of legislation a commentary indicating its meaning and effect in simple language. This practice is followed by many draftsmen of subordinate legislation, but it is unusual to find an explanatory note attached to primary legislation. In the course of the legislative process it is very common for the draftsman to furnish assistance to the legislators in the understanding of bills by indicating the function and effect of the bills as a whole and of individual clauses. If that can be done for legislators there ought to be no real difficulty in spreading the same enlightenment by providing the same assistance to the general reader.

The function of ensuring widespread availability of legislation in an up-to-date and intelligible form with accompanying explanatory material ought to be part of the process of legislative drafting. Unfortunately, there are very few indigenous draftsmen in any Pacific territory that I visited. The expatriate draftsmen tend to be very heavily committed with the burden of drafting new legislation. They serve on contract for finite terms, and thus have little opportunity for the detailed and sustained work of preparing compilations or reprints of primary or subordinate legislation. The solution that has been adopted in almost every territory is to commission a draftsman from abroad to undertake the task.

There is a difference in usage with reference to the term 'revision' of statutes. In some jurisdictions revision is regarded as reprinting a principal statute with subsequent amendments. In others it means law reform or a process analogous to reform - reform on a limited scale. In the present context the expression 'need for revised editions' of laws in paragraph 1 ( $f$ ) of my terms of reference is interpreted as meaning the need for reprints. Of course, the fact that some legislative title has become encrusted with amendments that a reprint has become urgent may also trigger off the need for a fundamental re-appraisal of the legislation leading to reform. Here, however, the discussion deals only with the need for up-to-date texts of legislation.

\section{Cook Islands}

The most recent reprint of Cook Islands legislation may be divided into two parts. The first volume contains the Reprinted Ordinances of the Cook Islands Legislature and Regulations and Rules 1947-1965. The second volume is comprised of the Reprinted Ordinances and Bylaws of the Island Councils of the Cook Islands 1916-1965. The Cook Islands became 'self -governing' in 1965 on the enactment by the New Zealand Parliament of the Cook Islands Constitution Act 1964. Consequently the Reprints contain a compilation of all legislation in force in the Cook Islands on the acquisition of the status of self-government. Since that date no annual volumes have been issued. The Clerk of the Legislative Assembly issues loose copies of Acts of that Assembly in printed form, but no annual volumes have been issued since 1965. Some Government Departments (such as the 
Justice Department and the Office of the Advocate-General) have bound their own working copies of the Acts in annual collections and incorporated a rough index. But no annotations are issued. No reprint has been undertaken since 1965.

The special relationship between New Zealand and the Cook Islands creates a problem for the draftsman reprinting Cook Islands legislation. Thus, the Cook Islands Act 1915 (which was an existing law in force in the Cook Islands at the time of self-government) originally provided in s.153 that the civil jurisdiction of the Supreme Court of New Zealand extended to the Cook Islands. That section was repealed by the Cook Islands Legislative Assembly by the Cook Islands Amendment Act 1969 and replaced by a new s 153. In Tangata $v$ Speaker of the Cook Islands Legislative Assembly [1979] 2 NZLR 182 Speight J held that the new s.153 prevented the Supreme Court of New Zealand from entertaining a civil action relating to a matter that had arisen in the Cook Islands. And yet the New Zealand Legislature has never repealed or modified s.153, and in the 1976 Reprint of the Cook Islands Act 1915 issued by the New Zealand Parliamentary Counsel; it is the original s.153 that still appears without note or comment. Clearly there is a need for a close examination of all legislation, both primary and subordinate, in force in the Cook Islands in order that an accurate, comprehensive, and up-to-date Reprint may be prepared.

Some of the law in force in the Cook Islands is buried in the volumes of the New Zealand Official Gazette before 1965. Several Government officers referred to the almost insuperable difficulty of consulting the volumes, as no complete set seems to be available in the Cook Islands. And even if they were accessible, the task of running to earth any particular piece of legislation continuing to have the force of law in the Cook Islands would discourage all except the most persistent and meticulous researcher.

\section{Fiji}

The most recent annual volume of legislation was the LAWS OF FIJI, 1975. That volume was printed in 1977 and circulated in 1978. From inquires that I made both from government officers and from lawyers in private practice it appears that those who wish to receive the legislation as it is enacted place a standing order with the Government Printer. Until a bound volume containing the usual apparatus of indexes is published, they undertake their own private annotation and revision. The last complete edition of the revised LAWS OF FIJI was published in 1967.

There is clear need for assistance not only in accelerating the process of publishing the annual volume of statutes, but also in the preparation of an up-to-date reprint of the LAWS OF FIJI. I was not entirely sure where the responsibility lay for the delay in the publication of annual volumes of the LAWS OF FIJI. I was given varying explanations. But there is nothing peculiar to Fiji in that. The reality seems to be that the work of publishing annual volumes of legislation is not always given high priority. 


\section{Kiribati}

On 1 October 1979 the current legislation of Kiribati was contained in the three volumes of the LAWS OF THE GILBERT AND ELLICE ISLANDS comprising the ordinances and subsidiary legislation thereunder in force on 1 July 1973 together with certain United Kingdom Orders in Council and other provisions relating to the Crown Colony of the Gilbert and Ellice Islands. However a new reprint (prepared by a former Attorney-General of the Colony) had only just been completed. The new reprint included all legislation in force in Kiribati as at 31 December 1978. The first volume of the reprint had been posted from the United Kingdom while I was in Kiribati. The work of preparing the reprint and seeing it through the press had been undertaken by the same former Attorney-General who had been responsible for the 1973 reprint, and had been commissioned by the United Kingdom Government.

Mr C J Lynch had been commissioned by CFTC to prepare a report for the Beretitenti (President of Kiribati) on the amendments that would be required to the existing laws and to United Kingdom legislation in order to bring those laws and legislation into conformity with the provisions of the Kiribati Constitution. Because of the departure of the AttorneyGeneral before independence and the absence of any other properly qualified person $\mathrm{Mr}$ Lynch had been asked to defer further work on that project and to accept the duties of Attorney-General until a permanent appointee from Fiji could take up the duties of the office. The ongoing function of maintaining up-to-date reprints will rest with the Attorney-General and his officers.

\section{Solomon Islands}

The current reprint of the laws of Solomon Islands is contained in the six volumes of the Ordinances of the British Solomon Islands Protectorate which includes all Ordinances enacted up to December 1969 and in force on that date. One volume of statutory instruments as at 1971 is also available from the Government Printer in Honiara.

The Solomon Islands Government has recently requested the CFTC for assistance in obtaining a properly qualified lawyer to work on the revision and up-to-dating of the Laws of Solomon Islands. The request seems to me to go beyond the preparation of a reprint, because the Government has in mind modifications and amendments to the current law, in order that it may conform more closely with the current political situation [ie that of an independent sovereign state].

The terms of reference proposed for such a legislative draftsman certainly include the preparation of a Reprint, which may possibly be justified as the first step towards the thoroughgoing reform which the Government of Solomon Islands would like to see in its statute book. 


\section{Tonga}

The current edition of the LAW OF TONGA (three volumes) was published in 1967 pursuant to legislative authority enacted the previous year. The time has arrived for a completely fresh reprint. In financial terms any reprint is bound to be uneconomic and for that reason some reluctance has been expressed about funding a new reprint. Such an approach is wrong in principle. A Government's duty to make the laws available to its citizens is not to be measured in terms of dollars and cents.

\section{Tuvalu}

As was the case with Kiribati the United Kingdom Government undertook as part of its post-independence aid to assist with the funding of a project for the revised edition of the laws of Tuvalu at a budgeted cost of $\$ 46,800$. The work was to be undertaken under the control of the Attorney-General. The legal authority for an authoritative reprint was conferred by the Revised Edition of the Laws Ordinance 1977 (No 3 of 1977) which refers, in express terms, to the desirability of modelling the revision on the Hong Kong Revised Edition of the Laws Ordinance 1965 but modified to dispense with the requirement for annual revisions after the publication of a loose-leaf edition. Hitherto any revision in Tuvalu had been the responsibility of a Law Revision Commissioner, but the proposed loose-leaf system would enable amendments to the laws to be incorporated regularly and frequently. The legislation also authorised the Attorney-General to compile future revisions and to incorporate them into the loose-leaf edition, so that as a result no need for a Law Revision Commissioner would arise in the future. When I was in Tuvalu I was informed that the work on the reprint of the legislation in force was almost completed.

\section{Western Samoa}

Anyone who wished to consult an annual volume of legislation enacted in Western Samoa after 1972 would be disappointed. The latest available volume was for that year. The volumes for 1973 and 1974 had been printed, but not published. Part only of the volume for 1975 had been printed. The seriousness of the time-lag was diminished during my visit to Apia by the appearance in Western Samoa of the first volume of the Reprint of the LAWS OF WESTERN SAMOA, with succeeding volumes to follow. This reprint, which will eventually consist of six volumes, is the work of the Parliamentary Counsel's Office in New Zealand under the scheme for bilateral aid between New Zealand and Western Samoa. It is a superlative production. Great care has been taken to ensure the highest possible degree of accuracy and comprehensiveness. A novel feature of the Reprint is that it includes subordinate legislation arranged immediately after the relevant enabling statute.

Two comments may perhaps be made about the Reprint. Firstly, it is entirely in English. Given the source of the enterprise that is not surprising, but it is a pity that the 
Reprint does not also contain the authoritative text in Samoan, especially in view of the constitutional equality between Samoan and English: see Article 54 (2) of the Constitution of the Independent State of Western Samoa. Secondly, the Reprint seems to proceed on the assumption that the Constitution is a legal document of co-ordinate importance with general legislation, thus reflecting perhaps the preconceptions of lawyers nurtured in the tradition of parliamentary omnicompetence. The Constitution is to be found in alphabetical order among other legislation. The appearance of the Reprint will provide the base for the regular up-dating of the legislation of Western Samoa. The main task now remaining, at least for the present, is to complete a parallel reprint in the Samoan language.

\section{B Law Reporting}

Each of the independent Commonwealth states in the Pacific has inherited the common law tradition as part of its legal system. Reasoned decisions of judges form an integral and highly important part of that tradition. When a judgment deals with the interpretation of some piece of enacted law, the Court is performing a judicial function in partnership with the legislature. For these reasons, if for no other, it is essential that the judgments of the Courts on legal questions of interest to the community as a whole and to the legal profession in particular ought to be published in readily accessible form and without excessive delay.

Law reporting is a skilled art, and not merely a matter of publishing the bare text of miscellaneous judgments. It is a function that requires an organisational base for an efficient operation. Even in large and relatively sophisticated jurisdictions law reporting tends to be regarded as of little importance in the legal system. In a newly independent state law reporting should be given high priority and accorded a substantial degree of importance. There is much time to make up. There are large areas of unexamined law. There are many citizens, government officials and others, who need assistance in ascertaining the law. At heart the judicial function is a state function, no less important than the executive and legislative function - indeed it is inextricably involved in both functions.

In many jurisdictions it is standard practice for the judgments of the superior courts to be distributed to government officials on a circulation list. Thus in Kiribati copies of judgments of the High Court are circulated to 38 persons, including the principal archivist. This is satisfactory, as far as it goes; but two comments may be made. In the first place, such a procedure is essentially ephemeral. Heaps of undigested, unindexed judgments provide an uninviting diet for a busy official. In all probability the judgment will be given a cursory glance and then forgotten, passed beyond recall, unless the official has some internal system of marshalling and indexing the judgments. Secondly, the circulation is confined to government officials. But the law is not the preserve of government officials alone: it is essentially a public function. Cases are brought in public: the hearing takes 
place in public: the judgment is a public document, often delivered in public. It is anomalous that the end product of a rational and public process should be consigned to oblivion. Obviously lawyers in private practice will need to have access to judgments of the Courts in which they practise. But there are others in the community to whom the judgments of the Courts should be readily available. Without a system of reporting those judgments which deal with significant legal questions the community as a whole will remain in ignorance about a vital part of its own legal system.

Each of the Commonwealth Pacific States that I visited has its own constitution. The constitution is declared to be the supreme law of the State. In each case the High Court or the Supreme Court is declared to be the expositor of the constitution. Judges trained in the tradition of parliamentary sovereignty seem to have some difficulty in accommodating themselves to such a constitutional role. It is all the more important that their judgments on constitutional questions should be available in properly reported form, so that those decisions may be exposed to examination not only by commentators but by other judges either in the local jurisdiction or elsewhere. Only in such a way can the judicial process in the constitutional framework flourish as it should. Without the interplay of reasoned argument and the cross-fertilisation of rational judgment decisions on constitutional issues will remain private, stunted, and sterile.

A legal system is in some respects like a nation. It may be too strong to say that it should assert itself, but at least it has the right to self-determination. That right will remain enfeebled unless the system is aware of itself and can see where it is going. If its component parts (legislative and judiciary) are to depend on external sources for their strength the system will continue to be derivative and to that extent inconsistent with national independence. If the only law reports available within a jurisdiction are the English or the Australian or the New Zealand reports and especially if the judges are trained in the United Kingdom or Australia or New Zealand the decisions of the Courts will inevitably be coloured by the material available to them. When, as is invariably the case, the judges are trained in the United Kingdom or in Australia or in New Zealand, the will to resist that influence may be entirely wanting. In truth the judges may not even be aware of what is happening. It is all the more important that every reasonable measure should be adopted which would tend to encourage legal self-awareness. The availability of reports of the local courts is, I think, such a measure, albeit a modest one.

\section{Cook Islands}

There is not, and never has been, any series of reported judgments of the High Court of the Cook Islands. The ultimate appellate tribunal for the Cook Islands is the Supreme Court (now High Court) of New Zealand (and possibly the Judicial Committee of the Privy Council). Some judgments of the Supreme Court on appeal from the High Court have been reported in the New Zealand Law Reports which are to be found in the library of the 
High Court, but which are not generally available. Recently, the New Zealand Council of Law Reporting has approved a policy of including, at the editor's discretion, judgments of the High Court of the Cook Islands in the New Zealand Law Reports. Examples are Re Mitiaro Election Petition [1979] 1 NZLR supp 1-25 and Re Te-Au-O-Tonga Election Petition [1979] 1 NZLR supp 26-70. But the judgments so reported have been very special cases and obviously the series of law reports in one country is hardly appropriate as the avenue of reporting the judgments of another country's courts.

Any decision not to report judgments of the High Court of the Cook Islands amounts to a self-denying ordinance. From time to time the High Court will be called upon to deliver judgment on questions of great legal and constitutional importance. The reports of those judgments and of judicial decisions on issues of widespread legal interest should be available. As it is, anyone concerned to discover whether there is a decision in point on some question has no alternative but to sieve laboriously through the files of cases in the Registry of the High Court. It is difficult to develop a living body of case law under such circumstances.

\section{Fiji}

Persons who wish to receive judgments of the Supreme Court may place a standing order with the Government Printer (F\$15.00 per annum). They then receive cyclostyled copies of the judgments as delivered, but of course without index, digest, or the usual apparatus of law reporting. Lawyers in private practice informed me that they arrange for their own indexing and digesting where possible.

A series of law reports does exist. However, as at mid-1979 the latest volume was volume 15 for 1969. I was informed that the volumes for the years 1970, 1971, and 1972 were all at proof stage and still with the printer. The preparation of the judgments for reporting has been undertaken by one of the judges of the Fijian Court of Appeal. Printing and publication were responsibilities of the Government Printer. Although I see no objection in principle to the involvement of the Government Printer - indeed there are good arguments in favour - I do have some reservation about turning judge into reporter. Judges are not necessarily the best reporters, and should only undertake the work of reporting when no other suitably qualified person is available.

Apart altogether from the obvious importance for Fijians in having up-to-date law reports generally available, there are others outside Fiji who maybe concerned to have access to the reports of judgments of the Fijian Court of Appeal. That Court has jurisdiction to hear and determine appeals from other Pacific jurisdictions. Although such appeals form a very small proportion of all cases coming before the Court, the decisions of the Fijian Court of Appeal in all cases must be of real interest in those jurisdictions in which it is the ultimate appellate tribunal, perhaps even of binding force. 


\section{Kiribati}

There never has been any system of reporting judgments of the superior courts of the Gilbert and Ellice Islands Colony, and no suggestion has been made for reporting judgments of the High Court since independence. Previously appeals lay to the Fijian Court of Appeal, but under the Constitution a Court of Appeal was established and it held its first sitting in October 1979.

While in Kiribati I had the opportunity of reading all of the judgments delivered by the High Court for the period from January to September 1979. The judgments were kept in the Attorney-General's office in separate folders, but without index, digest, or other aid. The cases fell into three categories: firstly, judgments of the High Court sitting at first instance; secondly, judgments of the High Court on appeal from Magistrates Courts; and, thirdly, judgments of the High Court of its own motion pursuant to specific statutory authority on review of decisions of Magistrates Courts. Without exception, all of the cases dealt with criminal matters. The second and third categories showed many instances where the procedure or decision of the inferior court had been defective or irregular in some respect. Such judgments have an educative function, but unless they are made available in a form where they may be consulted in the future their lesson will be lost forever. Many of the cases dealing with infringements of statutes touched on questions of interpretation. There is little value in a definitive judgment on a point of statutory construction if it is to be consigned to the limbo of departmental files.

\section{Solomon Islands}

The judgments of the High Court and of its protectorate, colonial predecessor have never been reported. The current arrangements conform to the common pattern in other Pacific Commonwealth jurisdictions. Judgments considered to be of interest are distributed to those within government departments who are on the circulation list. Judgments on review are forwarded to the Magistrates whose decisions have been reviewed. The Registrar of the High Court has occasional requests from outside Solomon Islands for copies of judgments, and is ready and willing to supply copies. There is obviously a real need for assistance in arranging for the reporting of judgments on legal questions of general interest including those which deal with constitutional issues.

\section{Tonga}

In comparison with other Commonwealth jurisdictions in the Pacific Tonga has a long tradition of reporting the judgments of its superior Courts. There are now three volumes of the TONGAN LAW REPORTS. Volume 1 contains a selection of cases decided during the period 1908-1959 and was the work of a former Judge of the Supreme Court of Tonga. The second volume, also his work, covers decisions of the Land Court from 1923 to 1962 and judgments of the Privy Council of Tonga on appeal from the Land Court (1924-1961) 
and on appeal from the Supreme Court (1954-1961). The third volume, for which a later Judge of the Supreme Court was responsible, includes decisions of the Land Court and judgments of the Privy Council from 1962 to 1973.

There is no continuing machinery for the preparation and publication of law reports. The issue of volumes of law reports in the past has been dependent on the initiative of a Judge of the Supreme Court. The Chief Justice of Tonga and the Crown Solicitor consider that there is a need for up-dating the reports. If a properly qualified lawyer were available, that person's duties would include the preparation of the reports of cases decided since 1973 and the preparation of a brief digest and index of cases decided before 1973.

\section{Tuvalu}

The present High Court of Tuvalu is the successor of the pre-independence Court of the Ellice Islands, which in its turn evolved from the High Court of the Gilbert and Ellice Islands. To some extent the case law of Tuvalu coincides with the case law of Kiribati. Any publication of decisions of the High Court of the Gilbert and Ellice Islands Colony would therefore be of material benefit equally to Kiribati and to Tuvalu.

Sittings of the High Court take place infrequently. The Chief Justice of the Court resides in Solomon Islands and is able to dispose of the major part of his judicial work without travelling to Tuvalu. The Registrar submits cases to him, which he is able to dispose of "on the papers". Nevertheless the written decisions deal with matters of general importance in the administration of justice in Tuvalu, and ought to be available in a convenient form to those who may be interested in the questions that arise. At present there is no general file of judgments of the High Court. A researcher would have no choice but to work his way through the individual files until some relevant decision came to light.

\section{Western Samoa}

The judgments of the Supreme Court of Western Samoa have never been reported in conventional form. Through the initiative of the present Attorney-General (Mr Neroni Slade) three volumes of cyclostyled judgments have been prepared together with the usual apparatus of indexes and digests. Volume 1 includes cases determined by the then High Court and of the Supreme Court of New Zealand for the period 1921-1949: Volume 2 comprises decisions of those two courts for the period 1950 to 1959 . Volume 3 is more comprehensive: it includes decisions during the period 1960 to 1969 of the Court of Appeal of Western Samoa, the High Court before independence and the Supreme Court of Western Samoa thereafter, the Supreme Court of New Zealand until independence, the Land and Titles Court, Public Service Board of Appeal, and the Discretionary Review Board (Taxation). The three volumes are essentially private copies. 
There is a clear need for a public set of reports especially covering the period after independence and more particularly the years from 1969 to the present. The contrast is striking between the dearth of reports of decisions in Western Samoa and the wealth of published decisions of the courts and tribunals of American Samoa. Furthermore, with the growth of an independent Bar in Western Samoa there is a professional demand for a proper series of law reports.

\section{General}

Law reporting in the Commonwealth Pacific countries is virtually non-existent. Such systems as do exist are in a parlous state. Here is a major area in which assistance is needed. In any publishing venture of law reports financial questions will be used to justify delay if not total lack of interest. But for the reasons that $I$ have set out earlier the availability of statutes and of reports of judicial decisions is a matter of fundamental importance in any legal system. This may be a field in which co-operation on a regional basis would be advantageous, especially in view of the common heritage of law which the individual countries enjoy and of the fact that many of the legal questions in one country will be of interest in other jurisdictions in the Pacific Region. As a member of the New Zealand Council of Law Reporting I am aware of the very considerable difficulties in establishing a system of law reporting; nevertheless I am convinced that those difficulties should not be allowed to outweigh the great need to which I have referred. The CFTC may be able to assist in the planning of some regional organisation which would include among its terms of reference the function of publishing reports of judicial decisions from Courts in the Commonwealth Pacific jurisdictions, a kind of South Pacific Council of Law Reporting.

\section{FOREIGN AFFAIRS: LEGAL NEEDS}

One of the most pressing problems confronted by a state on attaining independence relates to treaty succession. What international agreements are formally considered to bind the newly independent state? Should the obligations imposed by those agreements be accepted as continuing to bind the new state? What interim arrangements should be made until a decision is made? These are some of the questions that arise with pressing urgency during the period leading up to independence and for some considerable time thereafter. The extraordinary complexity of current international life makes it imperative that a modern state has expert legal assistance in handling foreign affairs. Furthermore, the range and functions of international organisations involve a modern state in a continuing relationship with international bodies and raise a concomitant need for advice on a host of questions that flow from that relationship.

The newly independent states have few, very few, persons qualified in international law. They are almost entirely dependent on expert assistance from outside. In the field of treaty succession the United Kingdom Government has provided assistance to some of the 
Pacific Commonwealth states by the commissioning of an expert to examine and to report on the international agreements which the newly independent state might accept as binding upon it. Where several states have similar constitutional backgrounds there would seem to be great value in arranging for one and the same person to report and to tender advice on this subject.

The sheer magnitude of the task of obtaining information about international agreements is daunting. In order to assist in the basic search modern technological developments may provide most useful research tools. The QL (ie Queens Lawford) Systems treaty index is one of the most promising of those new developments. In each country that I visited I took the opportunity of discussing with Foreign Affairs officers whether they would derive significant assistance from access to such a system.

The response was, in principle, enthusiastic, but always subject to questions of cost and manpower. It is desirable to adopt a cautious attitude to the introduction of new technological developments. They carry the superficial appearance of simplicity, but without highly qualified persons who know their potential and their limitations - in short, persons who know what questions to ask. They can become expensive white elephants. An example of what may happen will illustrate the point. In one of the countries that I visited I spent some time with the permanent head of the department responsible for external affairs and with the chief legal adviser of the government explaining the functions of the QL Systems treaty index and what advantages might be derived from access to it. I had sample print-out pages with me to show them. After some considerable time the permanent head of the department mentioned that he thought that he might have seen something like the treaty index before. It then emerged in further conversation that four massive volumes of the index had been lying for some years in the bookcase of the permanent head's very own office! A relatively senior member of the legal advisory service had in fact attended a course in Canada under the auspices of the Canadian International Development Agency (CIDA) as long ago as 1973. The volumes of the treaty index had become available as a result of his attendance at the seminar. But as far as I could judge from what I was told, they had never been used. In another Pacific country I was informed that the senior legal adviser had attended the same seminar in 1973 and that after some prompting on his part the volumes of the treaty index had arrived in 1975. I formed the distinct impression that the index had not been used there either.

Those two instances go to confirm the importance of ensuring that any country which may wish to use the QL Systems treaty index is able to take full advantage of it. That means having expert and qualified persons, preferably trained in international treaty law, who know how to use it. The immediate usefulness for newly independent states of an index along the lines of the QL Systems Index lies in the area of treaty succession. Up to 
the present time the Commonwealth Pacific countries have relied upon foreign experts for advice.

\section{A Cook Islands}

Whatever the position may be de jure, in fact the Cook Islands has a large degree of autonomy in the international arena. It has received considerable assistance from the New Zealand Government and particularly from the New Zealand Ministry of Foreign Affairs in international legal matters. The Secretary of External Affairs in the Cook Islands felt the lack of an authoritative catalogue of international agreements binding on the Cook Islands. As with so many other Commonwealth countries in the Pacific, he emphasized the need for assistance in the field of international law relating to treaty law generally and especially the law relating to international organisations of varying kinds from the United Nations at one extreme to the South Pacific Forum at the other.

Naturally in view of the very special relationship between Cook Islands and New Zealand there was a need for expert assistance in the consideration of special problems where, in the nature of things, the Cook Islands could not look to New Zealand for assistance. In determining its rights and obligations under international law as a selfgoverning, but not entirely independent, state Cook Islands needs highly qualified assistance. The raw materials of international law were almost completely lacking in the Cook Islands. There were no international law texts, very few treaties and other international agreements, and no complete collections of international decisions or awards. The Netherlands Government has offered some assistance under its programme of providing literature to governments in developing countries, and will provide some basic international law text books.

\section{B Fiji}

Fiji commissioned the late Professor D P O'Connell to advise on questions of Fiji's succession to international agreements. More recently a request was made to the CFTC for an international law expert to assist generally in the consideration of international legal problems as they affect Fiji, but especially on the ratification of international agreements and on the extent to which changes may be necessary in Fijian domestic law to ensure the due performance of Fiji's international obligations. It is hoped that with assistance from such an expert, who will be appointed for up to two years, the legal side of the Ministry of Foreign Affairs will acquire a broader base of experience. At the same time the Department has been able to take advantage of the service of an expert in legal problems relating to the sea and petroleum resources. 


\section{Kiribati}

The Secretary for Foreign Affairs in Kiribati was anxious that his Government should take full advantage of such an index as the QL Systems treaty index, but as with every other senior Government official with whom I discussed the problems of treaty succession he emphasized the fundamental need for properly qualified legal advice. Neither he nor his sole assistant had any legal training. When international legal problems arose he relied on advice from the Attorney-General. The then Attorney-General, the first appointed (albeit temporarily) since independence, had no international law experience. It is not common for an Attorney-General in any Government to have qualifications and experience in international law. In effect therefore, the Government of Kiribati is devoid of any local qualified international law advice.

To obtain expert advice on the question of treaty succession as it affected Kiribati the Government had commissioned (or was about to commission) a comprehensive report from Professor I A Shearer (of Australia). The decision to commission such a report seems to have been made in ignorance of the fact that the Government of Solomon Islands had only just received a report on the same topic from Mr Lloyd Jones of the United Kingdom. There are few divergences (if any) between the international agreements entered into by the United Kingdom Government before the independence of Solomon Islands and Kiribati with relation to each of those two territories. But such divergences would have been slight, because both Solomon Islands and Kiribati were previously entities within the British administrative region of the Western Pacific. It is unfortunate that a comprehensive report was not commissioned on the question of treaty succession affecting all of the former entities in the Western Pacific region as each became independent.

As with many states whose land territory consists of numerous islands Kiribati is faced with pressing problems relating to the delineation of its seaward boundaries and to the fixing of the boundaries of the territorial sea. I was informed that discussions with other Pacific states on the resolution of different points of view on this matter had been deferred in the absence of properly qualified expert advisers.

\section{$D$ Solomon Islands}

The Solomon Islands Government had only recently received from Mr Lloyd Jones of the United Kingdom a comprehensive report which it had commissioned on the international agreements which the Government might regard as binding on Solomon Islands consequent on independence. In preparing his report $\mathrm{Mr}$ Lloyd Jones had made use of the QL Systems treaty index. Consequently I would expect that the Government of Solomon Islands would have an appreciation of the possibilities of such a system.

Before independence the Solomon Islands constituted a United Kingdom Protectorate which for many purposes was treated as part of the British possessions in the Western 
Pacific. For that reason the material which Mr Lloyd Jones would have read and considered in relation to Solomon Islands would almost without exception have applied with equal force to other independent states which, prior to their independence, formed part of the British administrative region of the Western Pacific. Accordingly his report would seem to apply, mutatis mutandis, to those other states. However the terms of reference under which Mr Lloyd Jones was commissioned were limited to Solomon Islands and, of course, his report was presented to the Government of Solomon Islands.

\section{E Tonga}

There was an urgent need for qualified international lawyers, and the hope was expressed that CFTC might be able to assist in financing a qualified Tongan lawyer to attend a training course in international law. In the meantime the Government was anxious to establish a legal division of the Ministry of Foreign Affairs. This was an area in which CFTC might be able to assist by arranging for an international law expert to work in Tonga for a period of not less than a year in setting up such a division with a Tongan counterpart, preferably a qualified lawyer.

\section{F Tuvalu}

While I was in Tuvalu some of the Ministers and senior officials involved in the conduct of external affairs were at conferences abroad. From my discussions in Funafuti I formed the clear impression that precisely the same needs existed and the same problems arose in the international law sphere as were to be found in Kiribati and Solomon Islands. This was not surprising in view of the close relationship that had previously existed between Tuvalu and Kiribati when they formed constituent parts of the Gilbert and Ellice Islands administration.

By coincidence, during my stay in Tuvalu, a legal problem arose over alleged illegal fishing within the territorial waters of Tuvalu by a foreign fishing vessel. The vessel was taken into custody and the Master detained ashore, but the resolution of the charges required and will require careful consideration of legal issues, international as well as domestic. The Government's sole legal adviser is the Attorney-General, and it fell to him to consider the questions that arose. He had no materials to assist him in that task whatsoever.

\section{G Western Samoa}

Western Samoa is passing through an intensive development phase where many problems arise related to that activity. International and domestic law questions arise with respect to civil aviation and shipping. The relationship between Western Samoa and international organisations like ICAO and IMCO requires constant attention to the legal implications of any proposed courses of action. What conventions should Western Samoa 
adhere to? To which should the adherence be unconditional? What reservations (if any) should be entered to ratification or accession? In seeking the answers to those and other questions Western Samoa needs the assistance of expert advice. This seems to be a field in which the Technical Assistance Group could provide the best help.

\section{H Summary and Comment}

From a survey of the position in the Pacific territories that I visited the message is crystal clear. There is an almost total lack of local qualified international lawyers. The one or two local lawyers who have some training and experience in international law are heavily committed in other ways, and may well have become out of touch with international legal problems. It seems to me to be undesirable in principle that in the conduct of their international relationships the Pacific territories should have no option but to rely on outside expert advice. It is important that early measures should be taken to remedy this deficiency. The practice of international law demands legal skills of a very high order. The training of international lawyers takes years. By the very nature of their task international lawyers practise in the international arena. They are called upon to deal with other international lawyers, many of them extremely well-qualified and experienced. Every effort should be made to select competent persons for further legal training which will necessitate their attending courses in international law overseas at well-established universities and institutes.

There are three areas in which specific assistance may be offered. The first is at the level of selecting suitable candidates for further specialised training. Here outside assistance in assessing the merits of candidates would help to ensure that selections are made in accordance with appropriate standards. The second relates to the provision of financial assistance in the form of scholarships, supplementation bursaries and the like for attendance at international law courses overseas. The third is in the area of in-training assistance. It may be practicable for some Governments to provide such in-training within the legal division of their own Ministry of Foreign Affairs. The United Kingdom Government made arrangements of that kind before independence in some cases. The Commonwealth Secretariat may now be the most appropriate agency to act as a clearinghouse for concluding similar arrangements in respect of independent Commonwealth territories whose nationals need practical training in dealing with international law problems.

\section{LEGISLATIVE DRAFTING}

Whatever view one may take about the role of law in society and the legal needs of communities in the newly independent Commonwealth countries in the Pacific, it is abundantly clear that legislation at all levels has been and will continue to be an inescapable necessity. Until recently the role of the legislative draftsman has been down- 
graded. He has been looked on (perhaps it would be accurate to say "looked down on"), as a mere technician, a wordsmith, who has been content to apply United Kingdom legislation, mutatis mutandis, to colonial territories for which the United Kingdom had administrative responsibilities. Such an approach involves a basic misconception of the nature and function of legislative drafting. The task of the draftsman calls for legal skills of a high order. But it requires more. The draftsman must be attuned to the legal political and social needs of the community to which the laws are intended to apply. Ideally, he should be a 'man of the people'. It is extraordinarily difficult, if not impossible, for an outsider, no matter how wise and sensitive, to draft the legislation to be enacted by the local law-giver for the local community. It is therefore, in my judgment, important to give high priority to the nurturing of local legislative draftsmen. Unfortunately, old attitudes still persist not only among the permanent administrative officials, but also among politicians. It is necessary to evoke an appreciation of the high function of the law-makers.

In every single country that I visited there was an obvious need for law draftsmen. Even the expatriate draftsman is in short supply. Again and again I was told of proposals for new legislation that had been shelved for want of properly qualified legislative parliamentary counsel. The usual expedient for meeting the case where legislation is required urgently is for an expatriate to be commissioned to draft specific statutes, normally of a complex nature. In such cases individual governments have sometimes availed themselves of the assistance furnished through the good offices of the CFTC and, in some instances, of the United Kingdom Government.

\section{A Cook Islands}

There is a pressing need for a properly qualified law draftsman. At present, the responsibility for drafting devolves on the Advocate-General, who is already overcommitted with his duties as the chief permanent legal adviser of the Government. Under current administrative practice the preparation of an initial draft of proposed legislation is undertaken within the Government Department concerned. Once drafted the text is submitted to the Advocate-General for vetting. In fact, much of the legislation originates with the Advocate-General and, even where it does not, he finds that the task of checking the draft proposals is exacting and time-consuming. From the office of the AdvocateGeneral the draft legislation goes to Cabinet for final approval and ultimate submission to the Legislative Assembly. At the stage of discussion in Cabinet the Advocate-General may well be involved in detailed explanation of the text of the proposal and in discussion with administrative officials concerned with the implementation of the legislation once enacted.

Some legislation is drafted on behalf of Government Departments by lawyers in private practice. As has already been mentioned, the Cook Islands Government from time to time employs a firm of solicitors in private practice in Auckland, New Zealand. That firm has been responsible for the drafting of some legislation. Such arrangements may well prove 
to be the most satisfactory in the circumstances and especially where complex commercial legislation is involved. In principle however it is important that law drafting should become the province and function of a local properly qualified Cook Islander.

It appeared from discussions with officials in the Cook Islands that legislative drafting courses were considered highly desirable in theory, but that they expressed an element of caution about specific courses and an instinctive reaction that the course should be evaluated to ascertain what is being offered.

\section{B Fiji}

Fiji has several establishment posts for legislative draftsmen. There is a First Parliamentary Counsel and two posts at the Second Parliamentary Counsel level (one of which is filled by an appointee funded by the CFTC: the other post was unfilled). Even so, it was the unanimous and strongly expressed view of the officials to whom I spoke in Fiji that there was an acute and continuing need for law draftsmen, a need that was estimated to last for many years. It was in this field in particular that assistance under the auspices of the CFTC was most keenly sought, especially in the provision of short-term assistance.

Some reservations were expressed about the legislative drafting courses already offered. In the process of further discussion it appeared that the probable explanation for an element of disappointment was that the candidates who had attended drafting courses were not suited to the work. The officials with whom I spoke held strongly to the view that the only way for a law draftsman to acquire drafting skills is by learning "on the job". One or two candidates who had attended the drafting course in Ottawa, Canada, had returned somewhat dissatisfied. It was not clear whether those candidates had any commitment to legislative drafting either as a career in itself or as a useful and satisfying component of an all-round legal career.

Since Fiji is the one Pacific country where there is a sizeable legal profession with an established Law Society, I made inquiries both from Government officials and from lawyers in private practice as to the reasons why there was no apparent desire on the part of local lawyers to make a career as parliamentary counsel. The same explanations were given from each source:

(a) The nature of the work was not considered to be attractive to law graduates, who regard it as humdrum and lacking in the excitement of Court work;

(b) The scope of the work was thought to be too limited;

(c) The salaries offered were unattractive, being substantially lower than the income that might be earned in an average law practice; and 
(d) Furthermore, legislation is drafted in the English language, which for many Fijians is their second language.

Accepting that these explanations accurately reflect the attitudes of local lawyers, 1 consider that they provide a challenge both to Government lawyers in Fiji and to the Law Society in that country. Obviously much educative work must be done to show the true significance of the law draftsman in his proper place in the legal system.

It was difficult to assess what likely provision might be made by Fiji of candidates for the CFTC drafting courses. Because of their experience officials tended to under-estimate the extent to which Fiji might wish to take advantage of the courses. They emphasized the desirability of identifying candidates who had undertaken some training in law drafting and had evinced an interest in and revealed a bent for drafting.

\section{Kiribati}

Law drafting is a function of the Attorney-General's office. There is no establishment post expressly allocated for the appointment of a parliamentary counsel. There is an obvious need for comprehensive assistance in the drafting and revision of legislation to meet the requirements of the newly independent state. But at present Kiribati has no local citizens qualified in law at all. A couple are taking law courses at the University of PapuaNew Guinea. It is unrealistic to expect that on their graduating and return to Kiribati they will be sufficiently qualified to undertake the exacting work of law drafting. If they should show an interest in that work and if they can be spared from other legal duties, it would be very beneficial if they were to have the opportunity of attending drafting courses, and preferably those organised by the CFTC. Until the time arrives when there is a sufficiently qualified cadre of Kiribati lawyers, the demands of government will require that expatriates continue to undertake the work of law drafting. Some of those expatriates may be seconded to Kiribati for finite term: others may be commissioned to draft specific pieces of legislation. This is an area in which the CFTC may well be able to provide most valuable assistance.

\section{Solomon Islands}

The Attorney-General at the time of my visit to Solomon Islands was a career parliamentary counsel and assigned high importance to the work of legislative drafting. Within the Ministry of Law and Information there was an establishment post of legislative draftsman which was on offer to an expatriate at the time of my visit. As with many of the Pacific territories that have recently attained independence there is a dearth of locally qualified lawyers, and none with any experience in law drafting. In the foreseeable future there would continue to be a need for expatriate senior legislative draftsmen, although the officials to whom I spoke hoped that as and when qualified Solomon Islanders suitably qualified in law became available to the Government some of them would take up the 
work of legislative drafting. Until then it was hoped that Solomon Islands would be able to obtain assistance in the work of drafting specialised legislation either from CFTC or (in the case of complex legislation relating, for example, to petroleum) from the Technical Assistance Group. The Attorney-General referred to the aid that had been given from time to time by the British Institute of International and Comparative Law in furnishing comparative legislative materials.

Although some reservations were expressed in Solomon Islands, as elsewhere, about the usefulness of drafting courses, it appeared that the Government contemplated sending one or two candidates to such courses in the second half of 1980, including possibly, the second Assistant Attorney-General, who has already undertaken graduate work in law overseas. The common observation was expressed that "good draftsmen are born not made".

\section{Tonga}

The office of the Crown Solicitor carries out the work of legislative drafting in Tonga. In view of the multifarious responsibilities that devolve on the Crown Solicitor there is an urgent need for assistance in law drafting. The Tongan Government has obtained assistance from expatriate experts in the drafting of specialised legislation especially in connection with the establishment of a local banking facility. But there are other areas in which assistance is urgently needed. Some of the legislation in force in Tonga is singularly inappropriate to the present international and constitutional status of the kingdom. Thus, the law relating to trade marks (Registration of United Kingdom Trade Marks Act 1939) is a mere appendage of the United Kingdom trade marks legislation. There is no autonomous copyright or patents legislation. These examples relate to esoteric branches of the law, but they could be easily multiplied to reveal a large area in which a law draftsman could work to great advantage.

The Tongan Government had commissioned a retired military officer (formerly a Director, Legal Services) from the United Kingdom to visit the country and draft a code of military law. A proposal was mooted that, if appropriate funding could be arranged, he would be a most suitable person to draft a new Criminal Offences Act and Criminal Procedure Rules. The fact that the legal resources available to the Government are so slender makes it unavoidable that Tonga will continue to rely on such expatriate assistance as is available for the drafting of legislation even in spheres of common and general application.

Because of the sparse resources in manpower and money the Tongan Government has hitherto not been able to justify sponsoring any candidates for drafting courses, but the Crown Solicitor is anxious that Tongan lawyers should have an opportunity of attending such courses. The most effective mode of assisting Tonga with this aspect of legal work, as 
with others, would seem to be the provision of aid in setting up a legal division in government under the Crown Solicitor. Such an assignment would require the involvement of an expatriate lawyer, preferably under the auspices of CFTC, for not less than a year. One of the main tasks of that expatriate would be to organise the work of legislative drafting on a proper basis so that it might develop into a largely autonomous instrument with properly qualified local lawyers, relying on expatriates for assistance in legislative drafting only in exceptional cases of specialised or complex statutes.

\section{E Tuvalu}

As in Kiribati, law drafting in Tuvalu is a function of the Attorney-General, who is the only qualified lawyer in the country. A previous Attorney-General had drawn up a schedule of 30 statutes which in his view should be enacted by the Legislative Assembly, and during his term of appointment 12 statutes in that list had been enacted. There is a clear need for assistance in that field. The Prime Minister of Tuvalu had expressed the firm view that it was quite unsatisfactory to contemplate ad hoc assistance for a period of three months only, and had indicated that a minimum of twelve months would be required to complete the urgent work of legislative drafting. This was also the opinion of the current Attorney-General. No provision had been made on the establishment for a Legal Draftsman, but a suggestion had been mooted that such a post would be amply justified. What seems to be needed is an appointment that would give the Attorney-General some respite from his comprehensive responsibilities so that either he or his assistant might be able to devote time and study to the work of law-making.

There are at present no qualified Tuvaluan lawyers. Once that undesirable state of affairs has been rectified, it by no means follows that there will be a supply of suitably trained and experienced law draftsmen. At that stage it will become most beneficial for Tuvaluan lawyers to have the opportunity of attending drafting courses. Until then, however, the needs of government will continue to dictate the commissioning of expatriates to undertake the work of drafting statutes. Some of those expatriates may be seconded to Tuvalu for a finite term: others may be commissioned to draft specific pieces of legislation. This is an area in which the CFTC may well be able to provide most valuable assistance.

\section{F Western Samoa}

The office of the Parliamentary Counsel comes within the aegis of the AttorneyGeneral. It is the Parliamentary Counsel who is responsible for all legislative drafting. He has been an expatriate. Long term plans within the Attorney-General's office contemplated that a Samoan of some years standing might assume responsibility as Parliamentary Counsel, but his interests seem to lie in other directions. That is one of the problems that must always be recognised in the training of law draftsmen - it is a branch of 
law practice which calls for special skills, a special temperament, and a special cast of mind. It is unrealistic to expect a person to show an aptitude for and interest in legislative drafting simply because he has graduated in law.

Within the legal and constitutional context of life in Western Samoa the law draftsman performs a most important function. The Government depends very much on Parliamentary Counsel for advice at various stages in the legislative process. He also makes himself available to members of the Legislative Assembly and advises Parliamentary Committees. In that way he plays a significant role as an educator of ordinary members of the Legislative Assembly. As in the majority of newly independent states in the Pacific region the existence of a written constitution is a most important "fact of life" for the lawyer and not least for the law draftsman. In this respect it might perhaps have been more beneficial if those countries (including Western Samoa) had been served by law draftsmen trained in a legal system with a written constitution and entrenched constitutional rights and freedoms rather than by lawyers drawn from jurisdictions with omnicompetent (and sometimes unicameral) legislatures.

In the Attorney-General's office there are several recently qualified Samoan lawyers whose experience at the present stage is insufficient to justify sending them to drafting courses. The Attorney-General hopes that with a little more general experience legally qualified members of his office will gain substantial benefits from attending such courses. It seems that for some little time Western Samoa will need to rely on expatriate lawyers to provide the top level assistance in legislative drafting.

\section{G General}

The establishment of a standing course in the Pacific region in law drafting would not, I think, be justified at present. In view of the mixed reaction expressed about law drafting courses in other parts of the world I sense that there would be an insufficient supply of candidates for a standing course. In the meantime perhaps the most effective means of assistance would be the provision of financial assistance to enable local lawyers from Pacific countries to attend the courses that may be held elsewhere from time to time under the auspices of the CFTC. Another possible type of assistance would be the provision of financial aid for lawyers to be attached to well-established law drafting offices for training "on the job". If some Pacific regional law centre were to be established, that would be the appropriate venue for training law draftsmen from Pacific Commonwealth countries.

\section{TRAINING NEEDS AND NEEDS FOR SPECIFIC EXPERT ASSISTANCE}

It is easy for a lawyer to see legal needs in professional terms. But the lawyer needs continually to remind himself that legal facilities are provided in many communities by non-professional persons, be they lay judges or police officers. Anyone who is 
administering the law is in a sense providing legal services. It is obvious that a police officer who is arresting a person for a suspected offence needs to know the law applicable both to the alleged offence and to the act of arresting the alleged offender. So too a government official needs to know the nature and the extent of his legal powers when administering some legislative enactment. Even at the municipal level the servant of the municipality needs to have an appreciation of the legal aspects of his work. The complex ramification of rules and regulations in any society shows that its members are governed by law and not by men. The law is the concern of everyman! Unfortunately it has not yet proved to be feasible in any society, even in the most sophisticated, to ensure that all citizens are fully aware of their legal rights and responsibilities.

Under the terms of reference relating to my assignment I was asked to give specific consideration to the need for training courses for professional and para-legal staff for the lay judiciary and for police prosecutors. On any realistic assessment of the feasible it is appropriate to limit the need for legal education to the layman in that way.

\section{A Lay Judiciary}

Lay judges exercise jurisdiction in matters that may appear in financial terms to be routine or relatively unimportant. But the integrity of any legal system is not to be measured by such standards. The constant aim of any government and, indeed, of lawyers generally must be to attain the highest standards in the administration of justice at all levels, in the inferior courts no less than in the supreme court. Throughout the Pacific region there was a clear recognition of the need for constant training of lay judges, a recognition that seemed to me to be based on an equally clear perception of the important role that they play in the legal system of each of the territories.

\section{Cook Islands}

Apart from the two Commissioners, both of whom are laymen, there are a dozen lay judges in the Cook Islands, ranging in age from the early 30 s to mid-60. Plans were being made while $I$ was in the Cook Islands for the course of training for lay judges to coincide with the appointment of a new panel of laymen. The course was to be an intensive residential course of two to three weeks. It was the first of its kind in the Cook Islands. Lay judges were to attend from every part of the territory. There are problems of time and expense in securing the attendance of lay judges from some of the remote islands, such as Penrhyn at the extreme north of the Cook Islands. Because of infrequent communications such persons may be forced to remain away from their home base for many weeks at a time. Indeed I was told that the amount budgeted for the course was $\$ 5,000$ of which approximately half would need to be allocated to the costs of travel and accommodation for the lay judges coming from the far northern islands. In the light of such problems it goes without saying the assistance from the CFTC would be most beneficial, either in the 
form of funding or in the provision of staff to conduct or to assist in the running of the course.

\section{Fiji}

Although there are, in theory, three grades of magistrate in Fiji, there is only one grade in fact. It consists exclusively of professional judicial officers. Consequently, although there may well be solid justification in Fiji, as elsewhere, for regular opportunities for retraining and for refresher courses which professional judges may attend, the need for training courses for lay judges does not arise.

\section{Kiribati}

No systematic training courses have been undertaken for lay judges in Kiribati, although in 1979 the Chief Justice conducted a course for lay judicial officers and paralegal staff, which was attended by some of the Presiding Magistrates in Kiribati. Courses of that kind depend largely upon the initiative and enthusiasm of a person in authority. It is desirable that training courses should be undertaken as part of the normal administration of justice in a territory. The Chief Justice had followed up his close interest in the training of lay magistrates when he made inquiries at the Pacific Judicial Conference in Rarotonga in May 1979 about the systematic training of such judicial officers. Through the good offices of one of the New Zealand Magistrates (Mr W J Mitchell, S M) attending the Conference, the Principal of the Technical Correspondence Institute in Lower Hutt, New Zealand, furnished the Chief Justice with material used by the Institute in training courses for New Zealand Justices of the Peace. Those courses have been developed by a former Stipendiary Magistrate now on the staff of the Technical Correspondence Institute and are in accordance with the current policy of the Minister of Justice in the New Zealand Government to make greater use of lay judicial officers in the administration of justice in criminal matters. The Chief Justice regarded the Institute's comprehensive course as being of inestimable value in preparing training courses for lay magistrates in Kiribati. Insofar as the material prepared by the Technical Correspondence Institute is capable of easy assimilation by lay magistrates in Pacific territories it could serve a most useful purpose in inculating an awareness of fundamental values of universal application in the administration of justice. On the other hand a measure of caution is called for in assessing the extent to which foreign material prepared for an entirely different legal environment should be used in any particular territory.

\section{Solomon Islands}

Some of the Magistrates in Solomon Islands are not qualified lawyers, even the expatriates. At the basic level there are local courts with jurisdiction in respect not only over relatively minor criminal offences but also over civil matters. The personnel of those local courts are appointed by the Chief Justice. They are all unqualified in law and 
generally speaking apply customary law in the determination of the cases that come before them for decision. Clearly there is a need for training courses for such lay judges: that was recognised by the various officials to whom I spoke. As with other Pacific territories, the problems of organising such courses are formidable. This is an area in which the CFTC could play a most useful role which would be greatly appreciated in Solomon Islands and elsewhere.

\section{Tonga}

Tonga was the venue of a judicial seminar in 1977 which magistrates, both professional and lay, attended from a great many Pacific territories. Consequently there is an awareness in Tonga of the continuing need for training of judicial officers at all levels. No courses have been instituted as yet for lay judges in Tonga. In the application of the legal resources that are available in the administration of justice in Tonga it has been considered advisable to place emphasis on other areas, especially on legal education. It may be practicable to develop suitable training courses out of the programme of education for Tongans who wish to qualify for law practice. Once again, however, one of the basic problems must be overcome, that of personnel. Without some concerted and sustained effort to lay a proper basis for training courses, such training as can be provided by those who are already over-committed will never be completely satisfactory. Outside assistance is needed: it is the kind of aid that the CFTC is eminently well qualified to furnish.

\section{Tuvalu}

Apart from the Chief Justice and the Senior Magistrate (both of whom reside outside Tuvalu and exercise jurisdiction within the territory only as occasion demands) all of the judicial officers in Tuvalu are unqualified. In the special circumstances relating to the administration of justice in Tuvalu there is a strong case for providing assistance in the training of lay judges in two different ways. First, with outside assistance training courses should be conducted at regular intervals for as many judicial officers as are able to attend. It would be desirable that such courses should coincide with visits either of the Chief Justice or of the Senior Magistrate to Tuvalu. Courses of that kind are valuable also in assisting the lay judges to appreciate the importance of their function in the legal system of the country and fostering a kind of collegiate spirit which in its turn contributes to the development of self criticism and high standards. Secondly, lay judges should be encouraged to attend training courses outside Tuvalu. This is an area in which a group of Pacific countries might most profitably pool their resources with assistance from the CFTC.

\section{Western Samoa}

One of the Magistrates is a layman, but he has a background of long experience as Secretary for Justice and on occasions had presided in court as an Acting Magistrate. At the base of the judicial pyramid there are 11 lay magistrates exercising a limited 
jurisdiction, both in civil and in criminal matters. Many of those lay magistrates also hold office as Samoan Judges of the Land and Titles Court. Hitherto no systematic training courses had been instituted for those lay magistrates. However the Attorney-General was keen to take up a proposal that had been broached with the Chief Justice that a pilot project should be set up in Western Samoa. The suggestion involved setting aside almost a month for the programme which would be carried through with outside assistance in the main, but with a substantial contribution from the Attorney-General's office. Such a pilot project would provide useful lessons for the type of training course that would be best suited not only in Western Samoa but other Commonwealth Pacific countries which share many of the fundamental presuppositions about their legal system.

\section{B Professional and Paralegal Staff}

The staff of many Government Departments are closely involved in the administrative work of a legal nature. This applies particularly to the staff of the Courts and of legal departments. They all perform a useful function in the administration of the law. One of the difficulties experienced by the officials with whom I had discussions was that as soon as staff are trained to an acceptable level of competence they become eligible for appointment or promotion elsewhere. Until a career structure for public servants can be devised that gives proper recognition to the special skills required to service legal functions within Government the problem will recur.

Some training courses would be useful in assisting professional and paralegal staff to improve the standard of their work. In some jurisdictions local government officers (who come within the category of professionals involved in the administration of the law) have been given an opportunity to attend study courses abroad. In Fiji, where there is a comparatively strong Local Government Association, I was told that an officer in local government had attended a course in the United Kingdom. In various territories I was told that training courses would be very useful, especially for Court staff. In Western Samoa a New Zealand official had been seconded to assist with the training of Court staff within the country. The officials with whom I spoke in Cook Islands would also welcome such assistance although arrangements had been made from time to time for members of the Court staff to be sent to New Zealand for training at Registries of the (then) Magistrates' Courts and the Supreme Court.

There is a strong case for training courses for professional and paralegal staff involved in the administration of the Courts and other departments concerned with the administration of the law (land registration, companies, commercial affairs, patents, trademarks, to name but a few).

It is appropriate within the context of this topic to mention law libraries and staff to service them. It should be said at once that library facilities for lawyers, whether in 
government service or in private practice, are very bad. Not only are there comparatively few law books in any of the territories visited but in many cases fundamental texts are missing. Such law books as do exist are often singularly inappropriate to the legal realities of the jurisdiction in question - whoever may have been responsible in the past for the selection of books seemed to have little appreciation of the legal needs of lawyers on the spot. It is difficult, for example, to see what conceivable use Moyle's Institutes of Justinian might have in a Pacific jurisdiction, but I found a copy among the few law books on the shelves of a legal department in one territory! In another case I was shown some new acquisitions that had been bought out of a special grant but not one of the books dealt with legal problems of direct interest to the country - indeed that particular library did not possess the only books (three or four in number) that treat aspects of its own legal system and constitution. Thus in qualitative as well as in quantitative terms the holdings of law books are extremely disappointing. Of course, law books are very expensive. All the more reason for deploying to the best advantage what money is available.

For that reason this may well be a field in which it is wise to withhold the traditional response that might instinctively be taken to overcome such glaring deficiencies - namely by acquiring substantial numbers of books. We are on the brink of a revolution in library services in many spheres not least in supplying legal needs. Information science is becoming an instrument for satisfying those needs. Thus it may shortly be possible to convey a request for particular information to a central storehouse of legal material and for the data required to be furnished with very little delay. This kind of information retrieval may well be the answer to the needs of lawyers in Pacific Commonwealth territories. Once again the expense will be substantial. But this question should be posed: will it be cheaper in the long run to buy expensive sets of law materials which will be used infrequently and which will require replacement or up-dating every few years? I cannot believe that it will be cheaper than a permanent link to an information retrieval facility. It is a topic that will require careful and extensive study before substantial funds are committed to the acquisition of expensive law holdings.

\section{Lay Prosecutors}

In most of the Pacific territories that I visited prosecutions are in the hands of police officers who do not possess legal qualifications. Some prosecutions for offences against municipal ordinances are conducted by laymen other than police officers, but they are very much in the minority. There is, of course, nothing unusual in having prosecutions conducted by police officers. It is a commonplace throughout the English-speaking common law world. Nevertheless there is always a need for training of such prosecutors and not the less so in jurisdictions in which defendants are normally without the assistance of counsel. The traditional obligation on the prosecution to ensure that all of the relevant facts including those which may be favourable to the defendant are placed before the 
Court will apply with even greater force where the defendant is unrepresented. Furthermore without the constant challenge from counsel for the defendant to ensure that the prosecution proves its case in accordance with law the police prosecutor lacks an external standard against which to measure his performance.

In all of the countries that I visited I had discussions with judicial officers, with the Attorney-General, and with police officers, about the quality of police prosecutions. In almost every case there was a strong body of opinion that, although police prosecutors did their best, there was much room for improvement. In one jurisdiction a senior magistrate ventured the opinion that, if the presiding officer were to adopt an attitude of total judicial aloofness, over $90 \%$ of the prosecutions would be dismissed because of inadequate preparation and presentation. That seemed to me to be an exaggeration at the time, perhaps made for dramatic effect to highlight the deficiencies of police prosecutors. However the commissioned police officers in the same territory agreed that if prosecutors were left to their own devices and not assisted by the Court in the questioning of witnesses and in other ways the conviction rate would be very low.

\section{Cook Islands}

As a result of the difficulties under which law enforcement authorities had operated during the term of office of the previous government in that country the police had been subjected to very serious pressures for many years. Officials were unanimous that there was a great need to improve the standard of police prosecution work. Arrangements have been made in the past for police officers to go to New Zealand to undertake a six months course there including aspects of prosecutions. Some high ranking officers have had the opportunity of going to a command course in a Police College in the United Kingdom. The fundamental problem according to officials and to police officers in the Cook Islands with whom I had discussions was one of integrity in the carrying out of police duties including of course the decision when to prosecute and the conduct of prosecutions in Court.

\section{Fiji}

There is a very high standard of police administration in Fiji. There is a well-equipped Police Training College in Nasova, Suva. In that College courses have been conducted from time to time for prosecuting officers. These courses are residential and last for about six weeks. The curriculum is detailed and extensive. I discussed with the officers at the Police Training School a suggestion that police officers from other Pacific countries might attend courses at the School. It is clear that there are facilities at the School for further enrolments of that kind. The officers concerned would welcome the presence of police officers from other jurisdictions, subject always to any arrangements that might be made as between the Governments concerned. 
In spite of the pattern of instruction and the extensive training provided for police prosecutors, there was concern that in some cases there had been an apparent lack of proper legal advice in certain criminal prosecutions of a serious nature. It was also felt that senior police officers had become too heavily involved in the prosecution of defended cases where the defendant was represented by counsel or solicitor. To overcome problems of that kind it was made clear within the police force that where a plea of not guilty had been entered in a complex or difficult case against a defendant who was known to be legally represented then the papers were to be referred to the office of the Director of Public Prosecutions. As has already been mentioned (above Part II, B, 2), that office is comparatively well-staffed with qualified lawyers, and thus perfectly capable of handling the conduct of prosecutions against defendants represented by counsel.

\section{Kiribati}

Some of the police officers in Kiribati had attended Police Colleges in the United Kingdom where the course of instruction had included prosecution work. In Kiribati itself the Chief Justice had taken part in a short course for police prosecutors during 1978. There was a tendency on the part of the police to expect the Attorney-General to conduct the bulk of the prosecutions. That tendency had been resisted by the Attorney-General appointed on independence, who considered that the police should undertake a much greater number of the straightforward prosecutions, leaving to him or to the State Counsel the conduct of any cases that were out of the usual run. Police officers would welcome the opportunity to take part in regional courses for police prosecutors.

\section{Solomon Islands}

I had discussions with the officers at the Police College in Honiara. They considered that the month-long course which was offered for police prosecutors was not adequate. They were unanimous that prosecutors need to be trained "on the job". Instruction in the abstract can never be completely satisfactory. Many of the police prosecutors have difficulties with the English language in conducting cases in Court and are nonplussed when technical points arise. The deficiencies had recently been highlighted by the presence in Solomon Islands of two qualified lawyers appointed to the staff of the Department of Social Welfare to assist indigent persons in the conduct of their defence. These lawyers had completely altered the pattern of criminal proceedings in Court and had caused the police to re-appraise their work. Such a re-appraisal would have been inevitable in any event on the appointment of a Public Solicitor under the Constitution. Any imbalance should be corrected by the appointment of a Director of Public Prosecutions, also a constitutional office.

The only law book which deals with any aspect of Solomon Islands law is a manual for police prosecutors. It is available to all police officers involved in prosecution work. This 
manual is probably too detailed and too technical for those who will use it. Nevertheless it is very much better to have a manual of instruction than nothing at all.

\section{Tonga}

I had discussions in Tonga with police officers and also with the Minister of Police. The Prosecutions Department conduct most of the prosecutions in the Magistrates Court, but there is considerable turnover among the personnel in that Department. There are limited opportunities for specific training in prosecution work. The Tongan Police do conduct a 12-week course for police officers during which aspects of prosecution work are treated. The facilities at the Police Headquarters are adequate to accommodate some police officers from other Pacific countries if it should be decided to hold courses for police prosecutors on a regional basis. In the meantime a preference was expressed for arrangements under which one or two police officers a year might attend courses in New Zealand or Australia. Once again the view was expressed that there was a fundamental need for professional integrity so that without fear or favour police officers would advise their superiors that certain courses of action were right or wrong.

\section{Tuvalu}

Prosecutions throughout Tuvalu are conducted by police officers, although in Funafuti the practice had been for the Attorney-General to undertake the conduct of the more serious prosecutions. In view of the responsibility resting on the Attorney-General as the sole lawyer in Tuvalu it seems to be desirable that he should be freed from any prosecution work except in the gravest cases. In my discussions with police officers in Tuvalu it was clear that there was a need for training of police prosecutors, especially those from the outlying islands who have little opportunity for consultation with their colleagues. There was a preference for periodic training of police prosecutors at Funafuti itself rather than for the sending of selected police officers to courses abroad. This is an area in which considerable assistance could be offered by the CFTC, because it is unrealistic to expect any training to be undertaken by judges, magistrates, or local officials.

\section{Western Samoa}

At the Supreme Court level the conduct of prosecutions is in the hands of the AttorneyGeneral and members of his office. In the Magistrates Court and before other tribunals with limited jurisdiction in criminal matters the majority of prosecutions are undertaken by police officers. The Prosecutions Section consists of an Inspector, a Senior Sergeant, and six Sergeants. Hitherto members of the Attorney-General's office have participated in programmes of lectures for police prosecutors. A prosecutors' guide was prepared in January 1979 and is available to police prosecutors, but there is no regular programme of training. Police officers with whom I had discussions placed much importance on the training of police prosecutors "on the job" by attachment to more senior prosecutors. There 
was a measure of dissatisfaction about the effectiveness of courses in which police officers were involved in abstract study and mere observation. The experience of those who had attended training courses overseas indicated that, although superficially successful, the officers concerned had in fact encountered considerable problems with the language of instruction and with an unfamiliar environment. There was a strong preference for a pattern of training within the structure of active prosecution work.

The practice adopted within the Department had been to select an officer for training in prosecution work. Although this was not regarded as promotion, the selection tended to give the officer an advantage in any future consideration for promotion because of his exposure to different experiences and because of the need to develop skills in writing reports, preparing submissions, appearances in court and the like. The officer selected would act as an understudy with a senior prosecutor for a month. Then he would undertake prosecutions before a Samoan Magistrate and with further experience graduate to prosecution work before the Stipendiary Magistrate.

\section{General}

There is a widespread acceptance of the need to provide training for police prosecutors. Some favour the idea of attendance at courses within their own country Others see benefits in sending police officers to attend training courses in other jurisdictions where similar conditions exists. On the basis of my discussions with police officers and government officials they would all welcome assistance from the CFTC in the establishment and conduct of suitable training courses, and in improving existing courses. How such assistance may be given most effectively will depend upon other more general factors and in particular upon the establishment of some regional law centre or unit of a similar kind.

\section{REGIONAL UNIT CONCEPT AND MODEL LEGISLATION}

It is obvious that the legal requirements of the newly independent Commonwealth countries in the Pacific cover virtually the whole range of legal services. Those needs are almost entirely unmet by local lawyers. Even with the assistance of expatriates, whose contribution though worthy of the highest praise does little more than prevent a desperate situation from getting worse, existing needs cry out for radical remedy. The realities of the situation demand a new and imaginative approach. It will take years for some of the territories to generate local legal services to the standard required for servicing a modern state and at the same time providing the citizens with advice and representation in legal matters. There is a strong case for different lines of development to be adopted and followed concurrently. In the first place individual governments should be given every encouragement and assistance to increase the number of locally qualified lawyers. At the same time facilities should be made available for the provision of legal assistance to 
governments as and when the occasion demands. The facilities should be organised on a permanent basis, so that they may be provided for individual cases at any time.

Such a facility may be thought of in terms of a regional unit or a regional law centre. It would consist of a few qualified persons with wide experience in the skills that would be called upon most frequently, such as law drafting. Whether the unit would be attached to some existing institution in the region is a question of policy that would need to be considered carefully. Important specifications for the unit would be flexibility and mobility. Among its functions would be advising on the best methods of training lawyers, lay professionals and police prosecutors. I contemplate that if such a unit were to be acceptable as a means to assist in overcoming the massive deficiencies in legal services in the Pacific it would not only provide services itself through the members of its staff but also act as a clearing house or liaison body for tapping the various sources of assistance available to help in those areas where it was unable to act itself or where for any reason help should be sought elsewhere. It goes without saying that the establishment of such a regional legal unit would not preclude any government from seeking and obtaining legal assistance from other quarters and in particular from the CFTC or associated bodies.

I discussed the concept of a regional legal unit with the officials in each of the countries that I visited. There was general and enthusiastic support for such an idea. One of the features of a regional unit is that it would be much less remote than other intergovernmental agencies from which assistance has come in the past to individual Pacific countries. In its nature it would be in frequent, indeed even perhaps constant, communication with the legal departments of the region. It would be a natural function of such a unit to pool problems of common concern and to share ideas of common interest.

\section{A Model Legislation}

In each country visited I discussed the role of model legislation as possibly meeting some of the problems caused by the lack of skilled law draftsmen. In general there was basic support for the idea, but tempered with a note of caution that the subject-matter of any model legislation should be one of common interest and concern to the countries of the region. It was also emphasised that in many instances individual countries would need expert assistance in determining what modifications (if any) might be needed in adapting the model legislation to the local situation. In one or two countries there was a distinct note of reservation based upon previous experience, about the utility of model legislation. On further discussion I formed the impression that difficulties had arisen as a result of imperfect consultation about the applicability of proposed legislation to the local scene. Nevertheless even where doubts were expressed about the concept, there was a willingness to participate in any project of model legislation if it received general support from governments in the region. 
By way of testing the applicability of model legislation I took the opportunity, while in Western Samoa, to discuss with officials the Model Food Law which had been produced in January 1976 under the auspices of the South Pacific Commission by a Canadian Food Legislation Specialist (Mr R A Chapman). It was annexed to a report entitled "Food Legislation and Control in the Pacific Islands". In that instance Mr Chapman had worked in very close collaboration with relevant departments in all of the countries to which the legislation might apply and, as well, he had consulted with all relevant regional institutions. The result seems to have been received with great satisfaction. The duties under the legislation have been pitched at a level compatible with local expectations the powers and functions conferred on appropriate authorities have been fitted harmoniously into the existing framework of administrative powers and functions.

It appears that, where a particular subject-matter transcends national boundaries and covers circumstances applying indiscriminately to all countries to be affected, then there would be widespread acceptance of model legislation. I was reminded in one jurisdiction that it is not enough to have a project which is logically sound and which has inherent justifications. It is also necessary to sell the proposal to local people. Here we come back to a point that was made frequently by local officials. It is vital to make legislation simple and easy to understand.

\section{SUMMARY AND CONCLUSIONS}

(1) Part II of this Report deals with the factual position at the time of my visit with respect to the resources of legal personnel and the probable extent of dependence within government departments upon expatriates.

(2) Every single country in the region will need the services of some expatriate law draftsmen either because they have no local resources of that kind themselves or because their local resources are inadequate. At the very least seven parliamentary counsel will be needed from outside sources. In the circumstances obtaining in the countries all except Fiji and Western Samoa will require assistance at the level of Attorney-General or SolicitorGeneral and on my estimates at least 20 other expatriate lawyers will be required for some years to come. There will also be a substantial call on qualified expatriates to fill judicial posts for many years.

(3) Planning for the establishment of legal posts has tended to be limited and unimaginative.

(4) It would be desirable if a university in the region were to establish a specific course of study to enable properly qualified students from the region to gain law qualifications designed to equip them for practice in Pacific countries.

(5) Consideration should be given to setting up courses in elementary advocacy. 
(6) In some of the Pacific countries which have not received the benefit of recent reprints of their statutes provision should be made to assist in the preparation of such a reprint to be kept up-to-date.

(7) The factual situation within the region as to law reporting is set out in Part IV B.

(8) There is a great need to ensure that a system of law reporting is introduced in the region so that reports of judgments of general legal interest would be readily available on a proper and permanent basis.

(9) The factual position in each country within the region in relation to personnel and facilities for external affairs departments is set out in Part V.

(10) All of the countries in the region need assistance in the area of international legal work. There is an almost total lack of qualified staff; and facilities are virtually nonexistent.

(11) Where new techniques, such as the QL Systems treaty index, are considered for introduction, an evaluation should be made of the personnel and facilities to use the techniques to maximum advantage.

(12) Assistance in the area of training of international lawyers is urgently needed.

(13) That assistance should include:

(a) The process of selecting suitable candidates;

(b) Financial aid for attendance at international law courses; and

(c) Arrangements for in-training in the legal divisions of the Ministry of Foreign Affairs in other Commonwealth countries.

(14) The factual position in each country in relation to law draftsmen is set out in Part VI.

(15) Some reservations have been expressed about the effectiveness of existing law drafting law drafting courses.

(16) Assistance is needed in the provision of expatriate law draftsmen.

(17) In Tonga it would be helpful if expert assistance could be given in the setting up of a legal division.

(18) At present it is unlikely that the establishment of a standing course in the Pacific region would be justified.

(19) The factual position in each country in relation to lay judges is set out in Part VII.

(20) Assistance should be given in conducting courses for lay judges. 
(21) The proposed pilot project in Western Samoa for training lay judges should be assisted.

(22) Further investigation should be undertaken to assess the value and applicability of correspondence courses for lay judges on the lines of that provided by the Technical Correspondence Institute in New Zealand.

(23) Training courses for professional and para-legal staff associated with the Courts and Government offices should be established.

(24) Legal library facilities are deficient.

(25) Before measures are taken to provide substantial library acquisitions a study should be made of the feasibility of using information retrieval facilities.

(26) The factual position in relation to training of police prosecutors is set out in Part VII C.

(27) Some consideration should be given to regional training using existing facilities in police training schools.

(28) There is considerable room for improvement in the standard of prosecution work in the courts and assistance should be given in the conduct of training courses for police prosecutors.

(29) Favourable consideration should be given to the concept of a regional legal unit to provide assistance (directly or as an intermediary) in all aspects of legal work (including advising on training programmes).

(30) There is a place for model legislation in areas of common interest to countries in the region. 